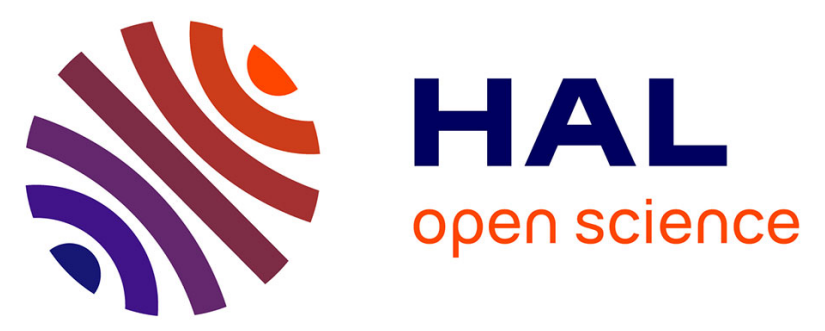

\title{
Coordination Chemistry of New Chiral P,N Ferrocenyl Ligands with Half-Sandwich Ruthenium(II), Rhodium(III), and Iridium(III) Complexes
}

Muh-Mei Wei, Max Garcia-Melchor, Jean-Claude Daran, Catherine Audin, Agusti Lledos, Rinaldo Poli, Eric Manoury

\section{To cite this version:}

Muh-Mei Wei, Max Garcia-Melchor, Jean-Claude Daran, Catherine Audin, Agusti Lledos, et al.. Coordination Chemistry of New Chiral P,N Ferrocenyl Ligands with Half-Sandwich Ruthenium(II), Rhodium(III), and Iridium(III) Complexes. Organometallics, 2012, 31 (18), pp.6669-6680. 10.1021/om300738q . hal-03157782

\section{HAL Id: hal-03157782 \\ https://hal.science/hal-03157782}

Submitted on 3 Mar 2021

HAL is a multi-disciplinary open access archive for the deposit and dissemination of scientific research documents, whether they are published or not. The documents may come from teaching and research institutions in France or abroad, or from public or private research centers.
L'archive ouverte pluridisciplinaire HAL, est destinée au dépôt et à la diffusion de documents scientifiques de niveau recherche, publiés ou non, émanant des établissements d'enseignement et de recherche français ou étrangers, des laboratoires publics ou privés. 


\section{Coordination chemistry of new chiral P,N ferrocenyl}

\section{ligands with half-sandwich Ruthenium(II), Rhodium(III) and Iridium(III) complexes}

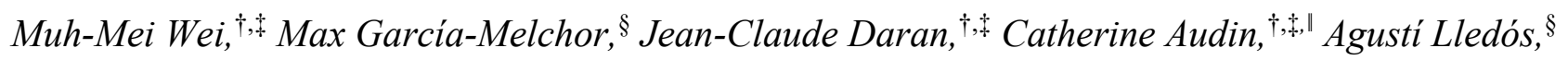

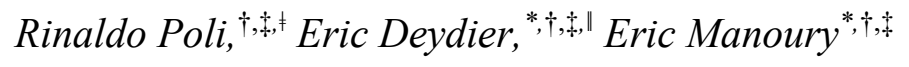

$\dagger$ CNRS, LCC (Laboratoire de Chimie de Coordination), 205 route de Narbonne, BP 44099, F-31077 Toulouse Cedex 4, France

\$ Université de Toulouse, UPS, INPT, F-31077 Toulouse Cedex 4, France

$\S$ Departament de Química, Edifici C.n, Universitat Autònoma de Barcelona, 08193 Cerdanyola del Vallès, Spain

॥ IUT A Paul Sabatier, Département de Chimie, avenue Georges Pompidou, BP 258, F-81104 Castres Cedex, France

‡ Institut Universitaire de France, 103 boulevard Saint-Michel, 75005 Paris, France 
TABLE OF CONTENT GRAPHIC

Chirality ?
$\underbrace{}_{\mathrm{M}=\mathrm{Ru}, \mathrm{Rh}, \mathrm{Ir}}$




\section{Keywords}

Chiral PN ferrocenyl ligand, Hydrogen transfer, Rhodium, Ruthenium, Iridium, DFT calculations, Halfsandwich complexes, Metal chirality.

\section{Abstract}

New half-sandwich ruthenium(II), rhodium(III) and iridium(III) complexes ( $p$-cymene) $\mathrm{RuCl}_{2} \mathrm{~L}$ and $\mathrm{Cp}^{*} \mathrm{MCl}_{2} \mathrm{~L}(\mathrm{M}=\mathrm{Rh}, \mathrm{Ir})$ where $\mathrm{L}$ is a planar chiral ferrocenyl tosylamine-phosphine ligand $\{1,2-$ $\left.\left(\mathrm{TosNRCH}_{2}\right)\left(\mathrm{PPh}_{2}\right) \mathrm{C}_{5} \mathrm{H}_{3}\right\} \mathrm{FeCp}(\mathrm{R}=\mathrm{H}, \mathrm{Me})$ coordinated in a monodendate fashion $\left(\kappa^{1}: P\right)$ have been synthesized and fully characterized both in solution (multinuclear NMR, mass spectrometry) and in the solid state (X-ray analysis on single crystals). Intra and inter molecular $\mathrm{N}-\mathrm{H} \cdots \mathrm{Cl}$ bonds were observed. Variable temperature NMR shows equilibrium between different structures which have been discussed with the help of DFT calculations. Addition of triethylamine to the complexes with $\mathrm{R}=\mathrm{H}$ allows removing the tosylamide acidic hydrogen giving rise to a ferrocenyl amidophosphine ligand coordinated in a bidendate fashion $\left(\kappa^{2}: P, N\right)$. All complexes have been fully characterized by multinuclear NMR and mass spectrometry. The structure of the iridium complex, determined by X-ray diffraction, shows a planar nitrogen atom and a stable metal-centered chirality. Only the most stable diastereoisomer, according to DFT calculations has been observed. A number of these complexes were assessed in the catalytic transfer hydrogenation and asymmetric transfer hydrogenation of acetophenone. 


\section{Introduction}

Homogenous asymmetric catalysis by transition metals has received considerable attention over the last few decades. Numerous chiral ligands and complexes allowing high efficiency reactions have been reported. In this area, chiral phosphines have played a significant role. ${ }^{1,2}$ The possibility to easily modify their electronic and steric properties by a judicious choice of the substituents has proven extremely useful to successfully optimized catalytic reactions. In recent years, the use of diphosphine ligands (P,P ligands) and monophosphine ligands containing an additional donor atom ( $\mathrm{P}, \mathrm{X}$ ligands) with a different "hard" and "soft" character (according to Pearson's HSAB concept) have been widely investigated. Among the numerous $\mathrm{P}, \mathrm{X}$ ligands reported to date, chiral bidendate $\mathrm{P}, \mathrm{N}$ ligands bearing a soft phosphine and a hard nitrogen provide interesting electronic and coordinating properties. ${ }^{3}$ Their coordination with transition metals affords efficient catalysts for numerous asymmetric applications such as hydroformylation and hydrosilylation. ${ }^{4}$

The nature of the nitrogen atom $\left(\mathrm{sp}^{3}\right.$ or $\left.\mathrm{sp}^{2}\right)$, the electronic effects of its substituents (alkyl, aryl) and their steric hindrance allow to easily modulate the nitrogen donor atom lability. Hemilability is of particular interest in catalysis, as these ligands allow the formation of reactive sites while improving the catalyst stability. However, the ability of chiral ligands to undergo rapid association/dissociation processes may be a problem in asymmetric catalysis, when the reaction selectivity is controlled by the metal stereochemistry. This is particularly true when the metal is an additional center of chirality in the ligand associated form. Indeed, reaction of a pure $R$ configurated bidendate ligand $\left(R_{\mathrm{L}}\right)$ will conduct to two diastereoisomers $\left(R_{\mathrm{L}} R_{\mathrm{M}}\right)$ and $\left(R_{\mathrm{L}} S_{\mathrm{M}}\right)$ and the selective formation of one specific diastereoisomer may be a challenge. ${ }^{5,6}$

One family of such chiral-at-metal complexes are the half sandwich complexes of ruthenium, rhodium and iridium, that have found efficient applications for instance in Asymmetric Transfer Hydrogenation (ATH). Ligands used for this reaction are mainly aminoalcohols or bidendate N,N ligands bearing a NH bond which is involved in the hydrogen transfer mechanism according to Noyori's proposal. ${ }^{7-11}$ However, a few research groups have reported non "NH" $\mathrm{P}, \mathrm{N}$ ligands active in Transfer Hydrogenation 
(TH). Among them, a few ferrocenyl phosphines have proven to be very efficient. Indeed, Stradiotto et al. recently reported ee's up to $95 \%$ in the ATH of sterically hindered ketones under mild conditions $\left(40^{\circ} \mathrm{C}\right)$ using a $\mathrm{P}, \mathrm{N}\left(\mathrm{sp}^{3}\right)$ ligand bearing a $\mathrm{NMe}_{2}$ group and $[\operatorname{IrCl}(\mathrm{COD})]_{2}$ as a metal precursor $(\mathrm{Chart} 1$, ligand 1). ${ }^{12}$ A similar efficiency was also reported using ruthenium catalyst 2 (Chart 1$)$ with a $\mathrm{P}, \mathrm{N}\left(\mathrm{sp}^{2}\right)$ ligand which involves a chiral oxazoline nitrogen atom donor. ${ }^{13-15}$ These examples suggest the occurrence of a different mechanism in Transfer Hydrogenation and various experimental or/and computational studies have been carried out to better understand the coordination chemistry of $\mathrm{P}, \mathrm{N}$ ligands and their role in $\mathrm{TH} .^{12,16-20}$

\section{Chart 1}

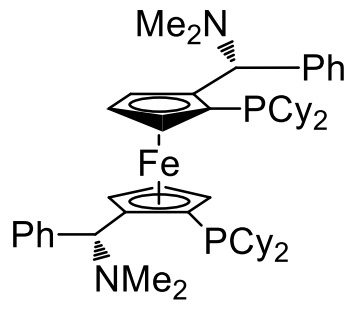

1

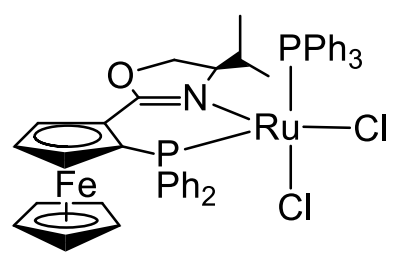

2

We have long been interested in the design and the synthesis of new chiral ferrocenyl ligands for exploring new asymmetric catalytic reactions or for improving the existing ones. ${ }^{21-26}$ The important application of chiral ferrocene ligands in asymmetric catalysis is highlighted in recent reviews. ${ }^{27,28}$ In the present paper we report the synthesis and the coordination chemistry of a new P,N chiral ferrocenyl ligand, bearing a TosNR fragment $(\mathrm{R}=\mathrm{H}, \mathrm{Me})$, with ruthenium, rhodium and iridium half sandwich complexes. The facile $\mathrm{H}$ removal allows switching from a P-amino to a stronger P-amido donor. The ligand coordination and lability and the stereochemistry of the resulting complexes will be explored through both experimental and computational work. A preliminary evaluation of these complexes in ATH and asymmetric hydrogenation $(\mathrm{AH})$ will also be presented. 


\section{Results and Discussion}

\section{Ligands Synthesis.}

2-thiodiphenylphosphino(hydroxymethyl)ferrocene (3) was chosen as starting material for this work. This compound can be prepared in multigram quantities and isolated as a racemic mixture or in a pure enantiomeric form, opening direct access to chiral ligands. ${ }^{29}$ Moreover, the phosphino function is protected from oxidation by a sulfur atom allowing working in air. Ligands $\mathbf{5}$ and $\mathbf{5 a}$ were prepared in a two steps reaction by successive addition of $\mathrm{HBF}_{4}$ and tosylamide or methyltosylamide to a dichloromethane solution of $\mathbf{3}$ (Scheme 1) under the reaction conditions previously optimized for the synthesis of ferrocenyl phosphine. ${ }^{30,31}$ After purification by flash chromatography on silicagel, compounds 4 and $\mathbf{4 a}$ were obtained as yellow powders in quantitative yields and fully characterized by mass spectroscopy and multinuclear NMR.

Scheme 1. Synthesis of ligands 5 and $\mathbf{5 a}$.

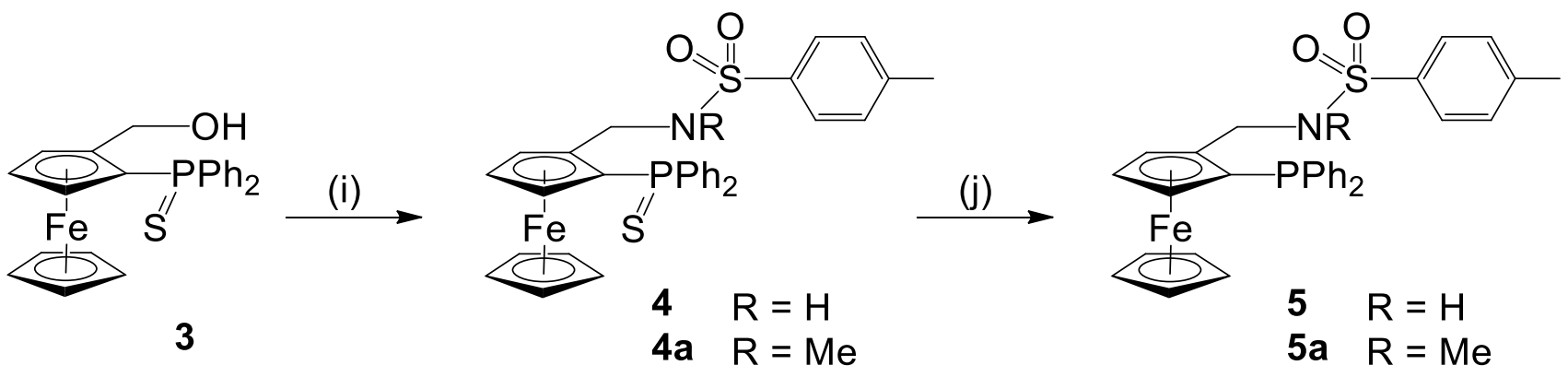

(i) $\mathrm{CH}_{2} \mathrm{Cl}_{2}, \mathrm{HBF}_{4}, \mathrm{H}_{2} \mathrm{NSO}_{2}\left(\mathrm{C}_{6} \mathrm{H}_{4}\right) \mathrm{CH}_{3}$ or $\mathrm{HNMeSO}_{2}\left(\mathrm{C}_{6} \mathrm{H}_{4}\right) \mathrm{CH}_{3}$; (j) reflux toluene, $\mathrm{P}\left(\mathrm{NMe}_{2}\right)_{3}$, overnight.

Compound 4 has been characterized by single-crystal X-ray diffraction. A view of the molecule is shown in Figure 1 and selected structural parameters are listed in Table 1. The sulfur atom is endo with respect to the $\mathrm{Cp}$ ring, being away from the ring plane by 1.013(3) $\AA$, as observed in related ferrocenyl derivatives. The two $\mathrm{Cp}$ rings are roughly parallel (dihedral angle of $\left.2.4(1)^{\circ}\right)$ and nearly eclipsed (twist 
angle of $\left.1.05(12)^{\circ}\right)$. The nitrogen atom is pyramidal $\left(\right.$ Sangles $\left.=338.0(2)^{\circ}\right)$ and endo with respect to the $\mathrm{Cp}$ ring with the hydrogen atom pointing to the sulfur atom $\mathrm{S} 1$ resulting in a intramolecular $\mathrm{N}-\mathrm{H} \cdots \mathrm{S}$ hydrogen bond (Table 2). All bonds lengths and angles in this structure are within expected range.

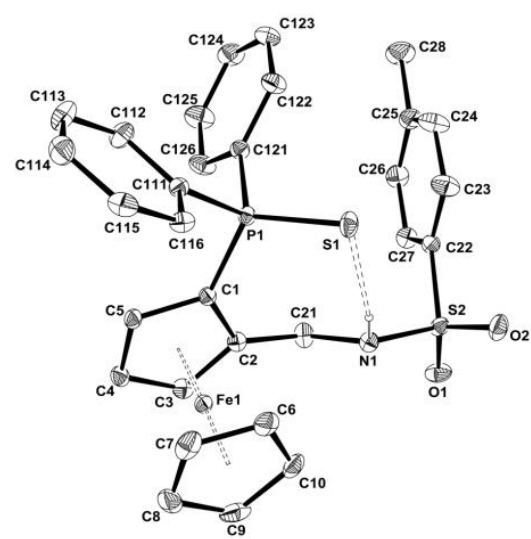

Figure 1. Molecular view of compound 4 with the atom labeling scheme. Ellipsoids are drawn at the $30 \%$ probability level.

Table 1. Selected bond distances $(\AA)$ and bond angles $\left(^{\circ}\right)$ for compound 4.

\begin{tabular}{ll} 
Distances & \\
\cline { 2 - 2 } Fe-Ct1 & $1.6406(7)$ \\
Pe-Ct2 $1-C 1$ & $1.6521(9)$ \\
P1-S1 & $1.7943(15)$ \\
C2-C21 & $1.9532(5)$ \\
C21-N1 & $1.497(2)$ \\
N1-S2 & $1.466(2)$ \\
S1-O1 & $1.6255(13)$ \\
S1-O2 & $1.4327(12)$ \\
\hline Angles & $1.4276(12)$ \\
\hline$* C t 1-F e-C t 2$ & $177.55(7)$ \\
C21-N1-S2 & $115.78(10)$ \\
C21-N1-H1A & $112.51(14)$ \\
S2-N1-H1A & $109.78(11)$
\end{tabular}

* $\mathrm{Ct} 1$ and $\mathrm{Ct} 2$ are the centroids of the $\mathrm{Cp}$ rings 
Table 2. Hydrogen bond parameters for compounds 4, 6, 8 and 10.

\begin{tabular}{lllll}
\hline & $\mathrm{N} 1-\mathrm{H}(\AA)$ & $\mathrm{H} \cdots \mathrm{X}^{*}(\AA)$ & $\mathrm{N} 1 \cdots \mathrm{X}^{*}(\AA)$ & $\mathrm{N} 1-\mathrm{H}^{\circ} \cdots \mathrm{X}^{*}\left({ }^{\circ}\right)$ \\
\hline $\mathbf{4}$ & 0.85 & 2.45 & $3.282(1)$ & 167.5 \\
$\mathbf{6}$ & 0.78 & 2.40 & $3.172(2)$ & 171.9 \\
$\mathbf{8}$ & 0.94 & 2.40 & $3.253(3)$ & 149.7 \\
$\mathbf{1 0}$ & 0.95 & 2.42 & $3.247(4)$ & 146.1 \\
\hline
\end{tabular}

$* \mathrm{X}=\mathrm{S}(\mathbf{4})$ or $\mathrm{Cl}(\mathbf{6}, \mathbf{8}, \mathbf{1 0})$.

Desulfurization was achieved with high efficiency using tris(dimethylamino)phosphine in refluxing toluene for $12 \mathrm{~h}$ under an argon atmosphere. Ligands $\mathbf{5}$ and $\mathbf{5 a}$ were recovered as yellow solids after flash chromatography (93\% and 100\% yield respectively) and fully characterized by mass spectrometry and multinuclear NMR.

\section{Coordination of ligand 5.}

Racemic 5 reacts in dichloromethane at room temperature with the half sandwich complexes $[\mathrm{RuCl}(\mu-$ $\mathrm{Cl})\left(\eta^{6}-\mathrm{p}\right.$-cymene $\left.)\right]_{2}$ and $\left[\mathrm{MCl}(\mu-\mathrm{Cl})\left(\eta^{5}-\mathrm{Cp}^{*}\right)\right]_{2}(\mathrm{M}=\mathrm{Rh}, \mathrm{Ir})$ to produce complexes $\mathbf{6}, \mathbf{8}$ and 10 respectively in quantitative yields (Scheme 2). All of these complexes have been fully characterized by multinuclear NMR and mass spectrometries and by X-ray crystallography.

Scheme 2. Synthesis of complexes 6, 7, 8, 8a, 9, 10, 11 


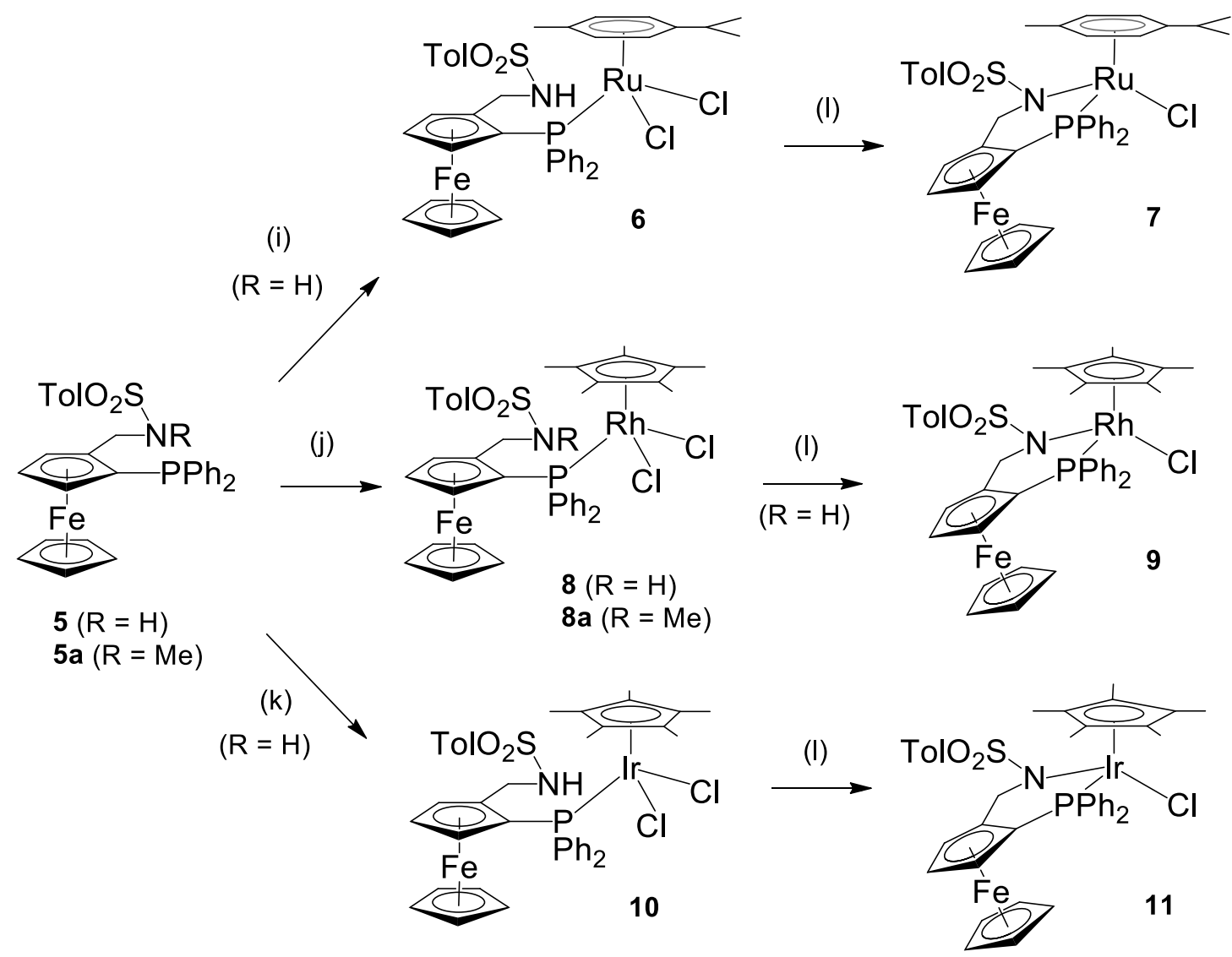

(i) $\mathrm{CH}_{2} \mathrm{Cl}_{2}$, room temperature, $\left[\mathrm{RuCl}_{2} \text { (Cymene) }\right]_{2}, 1$ hour. (j) $\mathrm{CH}_{2} \mathrm{Cl}_{2}$, room temperature, $\left[\mathrm{RhCl}_{2}\left(\mathrm{Cp}^{*}\right)\right]_{2}$, 1 hour. (k) $\mathrm{CH}_{2} \mathrm{Cl}_{2}$, room temperature, $\left[\operatorname{IrCl}_{2}\left(\mathrm{Cp}^{*}\right)\right]_{2}$, overnight. (1) $\mathrm{NEt}_{3}$ (5 equivalents), room temperature, overnight.

In all cases, the chloro-bridged dimer was cleaved by the phosphorus atom coordination while the nitrogen atom remains uncoordinated as shown by the X-ray structures. ORTEP views of the three geometries are presented in Figure 2. All three compounds adopt a roughly similar coordination environment with the phosphorus atom coordinated to the metal resulting in a "three-legged piano stool" geometry. A major difference is the presence of an intramolecular H-bond in the structure of 6, whereas those of compounds $\mathbf{8}$ and $\mathbf{1 0}$ feature an intermolecular $\mathrm{H}$ bonding network yielding infinite chains parallel to the $\left[\begin{array}{lll}1 & 0 & 0\end{array}\right]$ axis (Table 2). Compounds $\mathbf{8}$ and $\mathbf{1 0}$ are isomorphic in the polar P21 space group, whereas 6 crystallizes as a racemate in the centrosymmetric group P-1. 


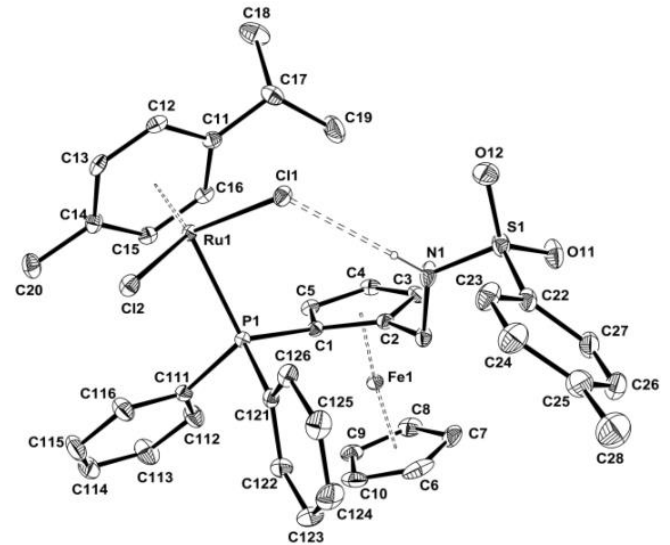

6

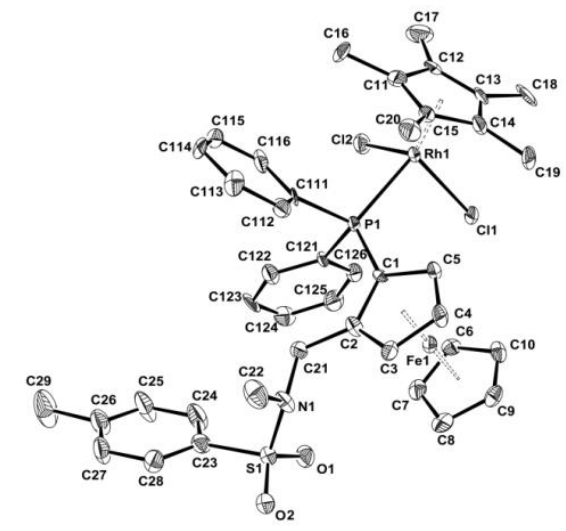

$8 \mathbf{a}$

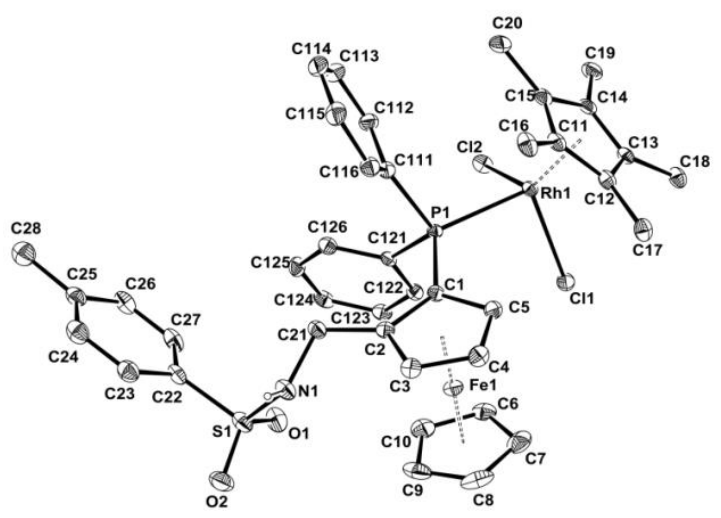

8

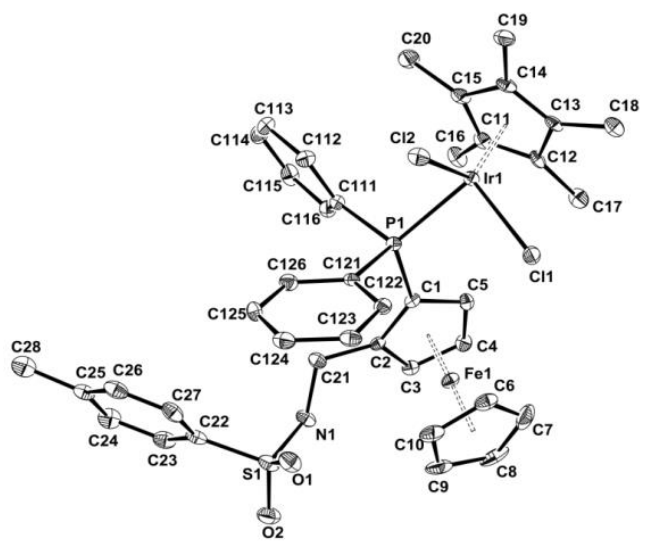

10

Figure 2. ORTEP views of compounds 6, 8, 8a and 10 with the atom labeling scheme. Ellipsoids are drawn at the $30 \%$ probability level. For the sake of clarity, $\mathrm{H}$ atoms are not shown except for the $\mathrm{NH}$ atom of compound $\mathbf{6}$ involved in the intramolecular hydrogen bond.

Examination of selected geometric parameters shows that the three structures have an essentially identical geometry (Table 3). The main differences are a smaller C11-M-Cl2 angle and larger distances of the N1 and P1 atoms from the ferrocene Cp ring plane in compound $\mathbf{6}$. These differences might be related to the intramolecular $\mathrm{N}-\mathrm{H} \cdots \mathrm{Cl1}$ hydrogen bond. Another difference of these structures is that the two Cp rings in compound $\mathbf{6}$ are nearly eclipsed with a twist angle of $4.0(2)^{\circ}$, whereas they are staggered in compounds $\mathbf{8}$ and $\mathbf{1 0}$ (Table 3). The hydrogen bond influences the M-Cl distance which is significantly longer in each compound relative to that of the free $\mathrm{M}-\mathrm{Cl}$ bond. Similar observations were reported by Cowie et al. for half sandwich ruthenium complexes bearing a P,amine ligand. ${ }^{32}$ The 
nitrogen atom in the structure of 6 is essentially planar with the sum of the angles equal to $359.4(2)^{\circ}$ whereas a significant degree of pyramidalization is observed in the structures of compounds $\mathbf{8}$ and $\mathbf{1 0}$ $\left(348.7(3)^{\circ}\right.$ and $351.1(4)^{\circ}$ respectively). A closer look at tables 2 and 3 shows that the $\mathrm{N} \cdots \mathrm{Cl}$ and N-S length in compound $\mathbf{6}$ are slightly shorter than in compounds $\mathbf{8}$ and $\mathbf{1 0}$. This result seems to suggest that the stronger H-bond in $\mathbf{6}$ increases the electron density on the $\mathrm{sp}^{2}$ nitrogen, which is then partially transferred to the sulfur atom through a $\pi$ interaction.

Table 3. Selected geometric parameters (distances in $\AA$, angles in ${ }^{\circ}$ ) for compounds 6, 8, 8a and 10.

\begin{tabular}{|c|c|c|c|c|}
\hline & 6 & 8 & $8 a$ & 10 \\
\hline \multicolumn{5}{|l|}{ Distances } \\
\hline $\mathrm{Fe}-\mathrm{Ct} 1$ & $1.6502(9)$ & $1.644(2)$ & $1.649(4)$ & $1.643(2)$ \\
\hline $\mathrm{Fe}-\mathrm{Ct} 2$ & $1.6555(12)$ & $1.657(2)$ & $1.653(4)$ & $1.663(2)$ \\
\hline M1-P1 & $2.3644(5)$ & $2.3656(8)$ & $2.355(2)$ & $2.3375(11)$ \\
\hline $\mathrm{M} 1-\mathrm{Ct} 3$ & $1.6973(8)$ & $1.8295(4)$ & $1.827(4)$ & $1.833(2)$ \\
\hline M1-Cl1 & $2.4123(5)$ & $2.4008(9)$ & $2.388(2)$ & $2.4059(12)$ \\
\hline $\mathrm{M} 1-\mathrm{Cl} 2$ & $2.4087(5)$ & $2.4094(8)$ & $2.394(2)$ & $2.4114(11)$ \\
\hline $\mathrm{P} 1-\mathrm{C} 1$ & $1.8085(19)$ & $1.818(3)$ & $1.799(8)$ & $1.808(4)$ \\
\hline $\mathrm{C} 2-\mathrm{C} 21$ & $1.496(3)$ & $1.500(5)$ & $1.515(11)$ & $1.496(6)$ \\
\hline C21-N1 & $1.457(3)$ & $1.464(4)$ & $1.462(11)$ & $1.468(6)$ \\
\hline N1-S1 & $1.5903(18)$ & $1.614(3)$ & $1.627(7)$ & $1.615(4)$ \\
\hline $\mathrm{S} 1-\mathrm{O} 1$ & $1.4294(17)$ & $1.429(3)$ & $1.440(7)$ & $1.428(4)$ \\
\hline $\mathrm{S} 1-\mathrm{O} 2$ & $1.4307(17)$ & $1.427(3)$ & $1.425(7)$ & $1.429(4)$ \\
\hline $\mathrm{P} 1 \cdots \mathrm{Cp}$ (plane) & $0.447(3)$ & $0.235(6)$ & $0.266(12)$ & $-0.241(7)$ \\
\hline $\mathrm{C} 21 \cdots \mathrm{Cp}$ (plane $)$ & $-0.015(3)$ & $-0.008(6)$ & $-0.022(15)$ & $0.017(8)$ \\
\hline $\mathrm{N} 1 \cdots \mathrm{Cp}$ (plane) & $1.349(4)$ & $-0.595(7)$ & $0.00(2)$ & $0.595(8)$ \\
\hline $\mathrm{M} 1 \cdots \mathrm{Cp}$ (plane) & $2.731(3)$ & $0.249(8)$ & $0.212(18)$ & $-0.249(10)$ \\
\hline \multicolumn{5}{|l|}{ Angles } \\
\hline $\mathrm{Ct} 1-\mathrm{Fe}-\mathrm{Ct} 2$ & $174.32(5)$ & $176.03(9)$ & $176.9(2)$ & $175.93(13)$ \\
\hline Ct3-M1-Cl1 & $123.90(3)$ & $122.10(6)$ & $119.07(14)$ & $119.84(7)$ \\
\hline $\mathrm{Ct} 3-\mathrm{M} 1-\mathrm{Cl} 2$ & $124.98(3)$ & $119.54(6)$ & $121.74(16)$ & $122.59(7)$ \\
\hline Ct3-M1-P1 & $128.50(3)$ & $132.69(6)$ & $133.14(16)$ & $133.04(7)$ \\
\hline
\end{tabular}




\begin{tabular}{lllll} 
C11-M1-C12 & $87.46(2)$ & $91.96(3)$ & $92.91(8)$ & $89.28(4)$ \\
C11-M1-P1 & $91.89(2)$ & $93.19(3)$ & $92.19(8)$ & $93.41(4)$ \\
C12-M1-P1 & $88.09(2)$ & $86.51(3)$ & $87.25(7)$ & $86.87(4)$ \\
C21-N1-S1 & $123.63(15)$ & $119.92(24)$ & $118.8(6)$ & $119.9(3)$ \\
C21-N1-R1 & $120.21(20)$ & $118.60(29)$ & $114.9(7)$ & $120.3(4)$ \\
S1-N1-R1 & $115.59(17)$ & $110.20(24)$ & $117.3(7)$ & $110.9(3)$ \\
C2-C21-N1-S1 & $-130.35(17)$ & $-135.21(27)$ & $-128.9(7)$ & $135.8(3)$ \\
$\tau$ & $4.0(2)$ & $26.6(3)$ & $12.8(6)$ & $25.8(4)$ \\
\hline
\end{tabular}

In solution, the phosphorus atom coordination is easily followed by the downfield shift of the ${ }^{31} \mathrm{P}$ NMR signal. Upon coordination to the Ru atom in compound $\mathbf{6}$, the resonance of the free ligand at $\delta$ 24.2 is replaced by a sharp singlet at $\delta$ 14.6. The final product possesses two elements of chirality, namely the planar chiral ferrocenyl group and the metal atom. The latter is chiral because of the intramolecular hydrogen bond that involves one of the two $\mathrm{Cl}$ atoms. Thus, two diastereomeric pairs of enantiomers could in principle be obtained. The single resonance is presumably resulting from a rapid interconversion between the two diastereoisomers through the symmetric intermediate A (Scheme 3).

Scheme 3. Proposed equilibrium between two diastereoisomers of compound 6.

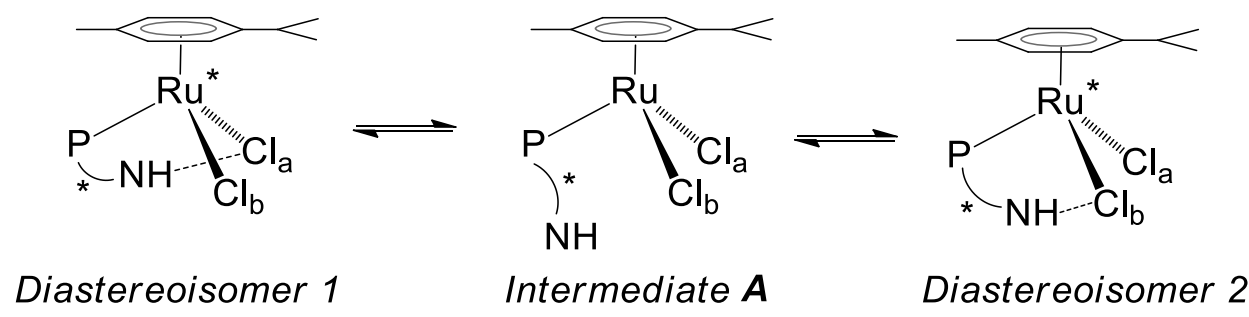

In order to probe the possible existence of isomers, variable temperature ${ }^{31} \mathrm{P}$ NMR investigations were carried out (Figure 3). Upon cooling, the $\delta 14.6$ signal shifted upfield and broadened, reaching maximum linewidth at $213 \mathrm{~K}$, followed by sharpening and further upfield shifting until a harp singlet was obtained at $\delta 11.3$ at $183 \mathrm{~K}$. Whereas a temperature-dependent chemical shift could result from a 
simple variation of the medium polarity (dichloromethane is known to have a strongly temperaturedependent dipole moment) and examples where this phenomenon occurs are common in ${ }^{31} \mathrm{P}$ NMR spectrometry, the broadening followed by sharpening unambiguously signals the presence of dynamic exchange phenomena. The single resonance observed at the slow exchange limit shows that one diastereoisomer is predominant with the minor isomer(s) remaining undetected.

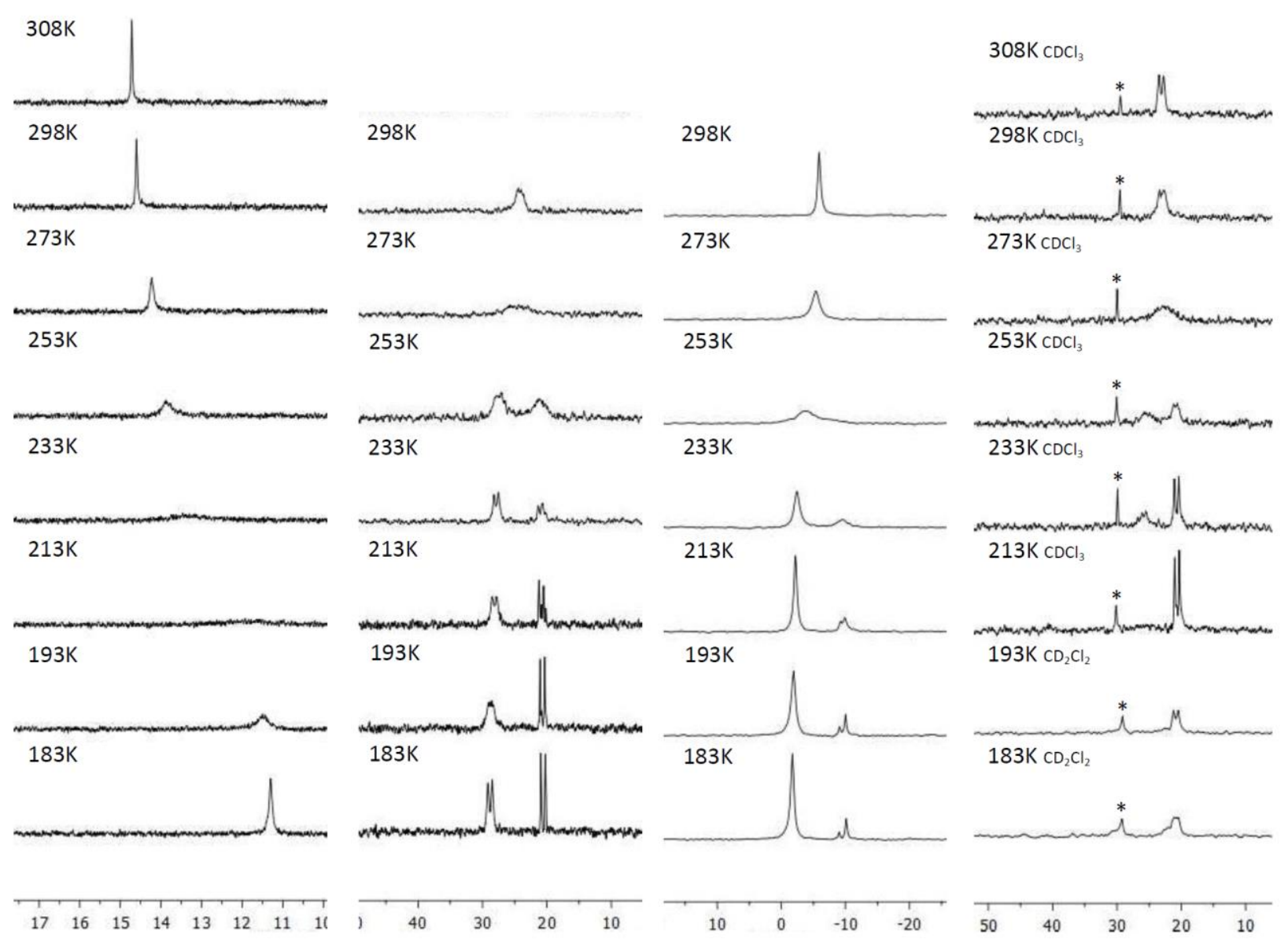

Figure 3. ${ }^{31} \mathrm{P}\left\{{ }^{1} \mathrm{H}\right\}$ NMR variable temperature analysis of compounds 6 (extreme left), 8 (middle left), 10 (middle right) and 8a (extreme right). The solvent used was $\mathrm{CD}_{2} \mathrm{Cl}_{2}$ unless otherwise indicated. The starred resonance in the spectrum of $\mathbf{8 a}$ corresponds to an impurity resulting from oxidation.

For the rhodium and iridium complexes $\mathbf{8}$ and $\mathbf{1 0}$, the ${ }^{31} \mathrm{P}\left\{{ }^{1} \mathrm{H}\right\}$ NMR spectra at room temperature gave broad signals at $\delta 24.2$ and -7.0, respectively. For both complexes, the resonance further broadens upon 
cooling without a significant shift and then decoalesces to yield two signals of unequal intensity at 253 $\mathrm{K}$ for $\mathbf{8}$ or $233 \mathrm{~K}$ for $\mathbf{1 0}$ (Figure 3). Further cooling to $213 \mathrm{~K}$ reveals the presence of at least three compounds. For complex $\mathbf{8}$, the spectrum at $213 \mathrm{~K}$ reveals a broad doublet at lower field around $\delta 28.8$ $\left(\mathrm{J}_{\mathrm{Rh}-\mathrm{P}}=141 \mathrm{~Hz}\right)$ as the major component, plus two higher field sharp doublets at $\delta 20.6\left(\mathrm{~J}_{\mathrm{Rh}-\mathrm{P}}=144 \mathrm{~Hz}\right.$, intermediate intensity) and $20.4\left(\mathrm{~J}_{\mathrm{Rh}-\mathrm{P}}=144 \mathrm{~Hz}\right.$, minor intensity). Complex 10 exibits a similar behavior, a broad signal (major) being observed around $\delta-1.8$ plus two higher field sharper singlets at $\delta$ -9.0 (minor) and -10.1 (intermediate). These observations would appear consistent with the equilibration hypothesis formulated for compound $\mathbf{6}$ in Scheme 3. Even though compounds $\mathbf{8}$ and $\mathbf{1 0}$ reveal an intermolecular $\mathrm{H}$ bonding in the solid state, their structure in solution could involve, like that observed for 6 in the solid state, an intramolecular $\mathrm{H}$ bond. Further investigations of this issue by DFT calculations will be shown later in section 4 .

3. P,amido complexes synthesis. Addition of five equivalents of triethylamine to dichloromethane solutions of complexes $\mathbf{6 , 8}$ and 10 yielded the P,amido complexes 7, 9 and 11, respectively, where the anionic nature of the amido ligand favors the ligand coordination in a $\kappa^{2}: P, N$ fashion with the concomitant replacement of a chlorido ligand (Scheme 2). All of these complexes have been fully characterized by multinuclear NMR and mass spectrometries. Unlike their precursors $\mathbf{6}, \mathbf{8}$ and 10, these complexes present sharp signals in the ${ }^{1} \mathrm{H}$ and ${ }^{31} \mathrm{P}\left\{{ }^{1} \mathrm{H}\right\}$ NMR spectra. The latter exhibits two signals with similar intensities: two singlets at $\delta 18.3$ and 26.6 for the ruthenium complex 7 , two doublets at $\delta$ $19.6\left(\mathrm{~J}_{\mathrm{RhP}}=147 \mathrm{~Hz}\right)$ and $30.9\left(\mathrm{~J}_{\mathrm{RhP}}=142 \mathrm{~Hz}\right)$ for the rhodium complex 9 , and two singlets at $\delta-0.9$ and -10.1 for the iridium complex 11. The simultaneous $\mathrm{P}$ and $\mathrm{N}$ coordination creates a non labile chiral center at the metal atom, giving rise to two possible diastereoisomers $\left(S_{\mathrm{L}}, S_{\mathrm{M}}\right.$ and $\left.R_{\mathrm{L}}, R_{\mathrm{M}}\right)$ and $\left(S_{\mathrm{L}}, R_{\mathrm{M}}\right.$ and $\left.R_{\mathrm{L},} S_{\mathrm{M}}\right)$

Crystallization of $\mathbf{1 1}$ from a dichloromethane/hexane mixture gave suitable crystal for an X-ray diffraction analysis. A view of this compound is shown in Figure 4. The chelating P,N ligand and one chlorine atom complete the coordination sphere of the three-legged piano stool, as observed in related compounds published in the literature. ${ }^{33-35}$ The distances and angles (Table 4) are in the normal range 
when compared to the related compounds. The structure presented corresponds to the $S_{\mathrm{L}}, S_{\mathrm{Ir}}$ diastereoisomer but as the space group is centrosymmetric the $R_{\mathrm{L}}, R_{\text {Ir }}$ enantiomer is also present within the crystal. The solid state ${ }^{31} \mathrm{P}\left\{{ }^{1} \mathrm{H}\right\}$ NMR spectrum of the crystals gave only one signal at $\delta-7.7$ and redissolution of the crystallized sample in $\mathrm{CDCl}_{3}$ give back only the signal at $\delta-10.1$, confirming the selective crystallization of the $R_{\mathrm{L}}, R_{\mathrm{Ir}} / S_{\mathrm{L}}, S_{\mathrm{Ir}}$ diastereoisomer. Consequently, the other ${ }^{31} \mathrm{P}\left\{{ }^{1} \mathrm{H}\right\}$ NMR signal observed at $\delta-0.9$ can be attributed to the $R_{\mathrm{L}}, S_{\mathrm{Ir}} / S_{\mathrm{L}}, R_{\mathrm{Ir}}$ diastereoisomer. Moreover, no conversion of $R_{\mathrm{L}}, R_{\mathrm{Ir}} / S_{\mathrm{L}}, S_{\mathrm{Ir}}$ to $R_{\mathrm{L},} S_{\mathrm{Ir}} / S_{\mathrm{L}}, R_{\mathrm{Ir}}$ was observed in solution by NMR in 4 hours at room temperature, showing that the inversion of configuration at the metal is not a facile process. This last observation underlines the metal ability to preserve its absolute configuration which is an interesting point for asymmetric catalytic applications. The observation also indirectly shows that the 1:1 diastereomeric mixture of $\mathbf{1 1}$ is produced under kinetic control.

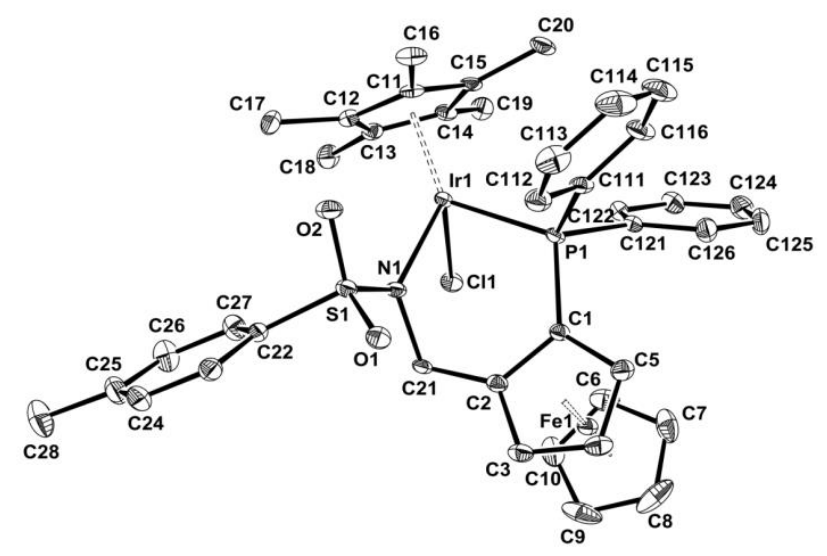

Figure 4. ORTEP view of compound 11 with the atom labeling scheme. Displacement ellipsoids are drawn at the $30 \%$ probability level. The $\mathrm{H}$ atoms have been omitted for the sake of clarity.

Table 4. Selected geometric parameters for compound 11. Bond distances $(\AA)$, bond angles $\left(^{\circ}\right)$, torsion angles $\left(^{\circ}\right)$.

\begin{tabular}{llll}
\hline Distances & & & \\
\hline Fe-Ct1 & $1.645(2)$ & P1-C1 & $1.807(4)$
\end{tabular}




\begin{tabular}{llll} 
Fe-Ct2 & $1.654(3)$ & C2-C21 & $1.491(6)$ \\
Ir1-P1 & $2.3119(11)$ & C21-N1 & $1.489(5)$ \\
Ir1-Ct3 & $1.8499(18)$ & N1-S1 & $1.579(3)$ \\
Ir1-C11 & $2.4348(9)$ & S1-O1 & $1.449(3)$ \\
Ir1-N1 & $2.160(3)$ & S1-O2 & $1.439(3)$ \\
\hline Angles & \multicolumn{5}{l}{} \\
\hline Ct1-Fe-Ct2 & $178.0(1)$ & C11-Ir1-N1 & $87.03(9)$ \\
Ct3-Ir1-C11 & $116.78(5)$ & P1-Ir1-N1 & $85.24(9)$ \\
Ct3-Ir1-P1 & $129.38(6)$ & C21-N1-S1 & $110.4(2)$ \\
Ct3-Ir1-N1 & $132.04(10)$ & C21-N1-Ir1 & $119.0(2)$ \\
C11-Ir1-P1 & $94.17(4)$ & S1-N1-Ir1 & $128.93(18)$ \\
\hline Other conformational parameters & \\
\hline C2-C21-N1-S1 & $-89.7(3)$ & Cp(plane)-C21 & $-0.028(7)$ \\
$\tau$ & $7.6(4)$ & Cp(plane)-N1 & $-0.958(8)$ \\
Cp(plane)-P1 & $-0.205(6)$ & Cp(plane)-Ir1 & $-0.342(9)$ \\
\hline
\end{tabular}

\section{DFT calculations.}

In order to test the hypothesis outlined in Scheme 3 as the reason for the observed low-temperature NMR behavior, we have carried out a DFT computational study. Computational details (functional, basis sets, solvent model, etc.) are given in the Experimental part. The three compounds geometries were fully optimized, without any ligand simplification using the $S$ planar chirality of the ferrocene ligand and starting from the geometry observed for compound $\mathbf{6}$ in the solid state. For the $\mathrm{Rh}$ and $\mathrm{Ir}$ complexes, analogous geometries adapted from that of $\mathbf{6}$ were built as starting points. Analogous starting structures were also generated for the other H-bonded diastereoisomers and for the open form. The energetic results are shown in Table 5 and the optimized structures are available in the supporting information (Part 1). The calculated bonding parameters in the optimized structures are in good agreement with those determined by X-ray diffraction for the experimentally observed isomers (see comparison in the SI, Part 2). The most stable structure corresponds to the $S_{\mathrm{M}}$ form for each metal, in agreement with observed geometry for the crystal structure of $\mathbf{6}$. This is true whether the comparison is made at the $E$ of $G$ level in the gas phase ( $\left.E_{\mathrm{gas}}, G_{\mathrm{gas}}\right)$ or in dichloromethane solution $\left(E_{\mathrm{sol}}, G_{\mathrm{sol}}\right)$, with the 
exception of compound $\mathbf{1 0}$ where the $R_{\text {Ir }}$ structure is slightly more stable, but only at the $E_{\text {sol }}$ level. The form without hydrogen bond has the highest energy. Thus, the calculations suggest that the intramolecular hydrogen bond between a chlorine atom and the pendant sulfonamide hydrogen atom stabilizes the structure. The complex with the highest energy difference between the open and closed forms is $6\left(7.7\right.$ and $5.1 \mathrm{kcal} / \mathrm{mol}$ at the $E_{\mathrm{sol}}$ and $G_{\text {sol }}$ levels, respectively), whereas this difference is of the order of 1-2 kcal/mol for compounds 8 and 10. This indicates that compound $\mathbf{6}$ forms a stronger $\mathrm{H}$ bond, in line with the X-ray structural results (Table 2). The two H-bonded isomers have very similar energy in the solvated model, the maximum difference being observed for 6 (3.9 and $2.0 \mathrm{kcal} / \mathrm{mol}$ at the $E_{\text {sol }}$ and $G_{\text {sol }}$ levels, respectively). This difference appears large enough to provide only one observable isomer for 6 in NMR spectrum of $183 \mathrm{~K}$, whereas the smaller energy differences for the isomers of compounds $\mathbf{8}$ and $\mathbf{1 0}$ would seem consistent with the observation of three resonances at low temperature for these compounds. On the other hand, the small energy difference associated with breaking and forming the $\mathrm{H}$ bond should in principle insure a very rapid equilibration on the NMR timescale for all compounds, leading to the expectation of only one average resonance at all temperatures (an exchange rate of $2.47 \cdot 10^{3} \mathrm{~s}^{-1}$ is calculated for the Eyring equation for a barrier of $7.7 \mathrm{kcal} / \mathrm{mol}$ at $183 \mathrm{~K}$ ). Hence, the computational investigation suggests that the forming and breaking of the $\mathrm{H}$ bond (Scheme 3 ) is unlikely to be the cause of the slow exchange phenomena observed by low-temperature NMR for compounds $\mathbf{6 , 8}$ and 10.

DFT calculations were also carried out on compound $\mathbf{1 1}$ in order to verify the relative energy between the two possible diastereoisomeric forms. The optimized geometries are shown in the SI (Part 3). The geometry of the experimentally observed $R_{\mathrm{L}}, R_{\mathrm{Ir}} / S_{\mathrm{L}}, S_{\mathrm{Ir}}$ diastereoisomer is in close agreement with that determined by X-ray diffraction (comparison available in the SI, Part 4). According to the theoretical calculations, the crystallographically characterized $R_{\mathrm{L},} R_{\mathrm{Ir}} / S_{\mathrm{L}}, S_{\mathrm{Ir}}$ diastereoisomer is $11.7 \mathrm{kcal} / \mathrm{mol} \mathrm{more}$ stable at the $E_{\text {gas }}$ level than the $R_{\mathrm{L}}, S_{\mathrm{Ir}} / S_{\mathrm{L}}, R_{\mathrm{Ir}}$ diastereoisomer. Inspection of the two optimized geometries, however, does not reveal any obvious reason for the lower stability of the $R_{\mathrm{L}}, S_{\mathrm{Ir}} / S_{\mathrm{L}}, R_{\mathrm{Ir}}$ diastereoisomer. 
Table 5. Relative energies (in $\mathrm{kcal} / \mathrm{mol}$ ) computed for the different isomers of compounds 6 (Scheme 3), 8 and 10.

\begin{tabular}{|c|c|c|c|c|c|}
\hline & Isomer $^{\mathrm{a}}$ & $\Delta \mathrm{E}_{\mathrm{gas}}$ & $\Delta \mathrm{G}_{\text {gas }}$ & $\Delta \mathrm{E}_{\mathrm{sol}}$ & $\Delta \mathrm{G}_{\mathrm{sol}}$ \\
\hline \multirow{3}{*}{6} & $N H^{\cdots \cdots} \mathrm{Cll}(\mathrm{S})$ & 0.0 & 0.0 & 0.0 & 0.0 \\
\hline & $\mathrm{NH}^{\cdots \cdots} \mathrm{Cl} 2(\mathrm{R})$ & 4.9 & 3.0 & 3.9 & 2.0 \\
\hline & No H bond & 7.9 & 5.2 & 7.7 & 5.1 \\
\hline \multirow{3}{*}{8} & $N H^{\cdots \cdots} \mathrm{Cll}(\mathrm{S})$ & 0.0 & 0.0 & 0.0 & 0.0 \\
\hline & $\mathrm{NH}^{\cdots \cdots} \mathrm{Cl} 2(\mathrm{R})$ & 0.8 & 3.0 & 0.4 & 2.5 \\
\hline & No H bond & 1.6 & 1.4 & 2.0 & 1.7 \\
\hline \multirow{4}{*}{10} & $N H^{\cdots \cdots} \mathrm{Cll}(S)$ & 0.0 & 0.0 & 0.0 & 0.0 \\
\hline & $\mathrm{NH}^{\cdots \cdots} \mathrm{Cl} 2(\mathrm{R})$ & 0.1 & 0.9 & -0.3 & 0.4 \\
\hline & No H bond & 1.3 & 1.3 & 1.3 & 1.3 \\
\hline & $R_{L}, R_{I r} / S_{L}, S_{I r}$ & 0.0 & 0.0 & 0.0 & 0.0 \\
\hline 11 & $R_{L}, S_{I r} / S_{L}, R_{I r}$ & 11.7 & 10.5 & 7.1 & 5.9 \\
\hline
\end{tabular}

(a) The symbol $S$ or $R$ in parentheses indicates the absolute configuration at the metal center, given that the absolute configuration used in the calculation for of the planar chiral ferrocene is $S$.

\section{Coordination of ligand 5a.}

Since the theoretical calculations do not support the explanation of the observed dynamic behavior for compounds $\mathbf{6 , 8}$ and $\mathbf{1 0}$ as a result of $\mathrm{H}$ bond forming and breaking (Scheme 3) and in order to throw further light on this phenomenon, we have synthesized a new ligand, 5a, bearing one methyl group on the nitrogen atom (Scheme 1). This ligand cannot establish N-H $\cdots \mathrm{Cl}$ interactions. Addition of 5a to a dichloromethane solution of $\left[\mathrm{Cp}^{*} \mathrm{RhCl}_{2}\right]_{2}$ afforded complex 8a in good yields (Scheme 2). This compound has been characterized by multinuclear NMR and mass spectrometries and by X-ray crystallography. It displays a structure roughly similar to those of $\mathbf{8}$ and $\mathbf{1 0}$, with the phosphorus atom coordinated to the metal and a dangling amine function, resulting again in a "three-legged piano stool" geometry. Selected geometric parameters for compound 8a are collected in Table 3. The main difference is that the ferrocene $\mathrm{Cp}$ rings in the structure of $\mathbf{8 a}$ form a dihedral angle midway between the eclipsed and staggered conformations. The room temperature ${ }^{31} \mathrm{P}\left\{{ }^{1} \mathrm{H}\right\}$ NMR spectrum of 8a shows a 
sharp doublet at $\delta 23.1\left(\mathrm{~J}_{\mathrm{Rh}-\mathrm{P}}=146 \mathrm{~Hz}\right)$ (Figure 3). However, decreasing the temperature leads to broadening and decoalescence in a qualitatively similar fashion and a similar temperature as compound 8. Two large signals are observed around $\delta 20$ and 26 at $253 \mathrm{~K}$. At $213 \mathrm{~K}$, the higher field signal becomes a relatively sharp doublet $\left(\mathrm{J}_{\mathrm{Rh}-\mathrm{P}}=143 \mathrm{~Hz}\right)$, whereas the lower field signal disappears in the noise. From this spectrum, it seems that a third minor component may also be present near the high field doublet, as seen for the analogous compound $\mathbf{8}$, although the quality of the spectrum does not allow an unambiguous conclusion. Therefore, a fluxional behavior also exists for compound 8a. As no hydrogen bond is possible here, we are drawn to conclude that the structures observed at the slow exchange limit are not related to the establishment of $\mathrm{H}$ bonding at all, but probably result from different conformers related to each other by restricted rotation around the M-P and/or the $\mathrm{P}-\mathrm{C}(\mathrm{Cp})$ bond. This hypothesis seems consistent with the minor effect of the $\mathrm{H} / \mathrm{Me}$ substitution in the qualitative behavior of the NMR spectra of compounds $\mathbf{8}$ and $\mathbf{8 a}$. Of course, it is not excluded that the H-bond seen for $\mathbf{6 , 8}$ and $\mathbf{1 0}$ in the solid state is maintained in solution and contributes to the stabilization of the observed conformers.

\section{Hydrogenation Catalysis.}

As half sandwich complexes of ruthenium, rhodium or iridium bearing $\mathrm{P}, \mathrm{N}$ ligands have shown efficiency in transfer hydrogenation and asymmetric transfer hydrogenation, we were prompted to investigate the activity of our compounds. Enantiomerically pure complexes $\mathbf{6 , ~ 8 , ~} \mathbf{1 0}$ were synthesized as described above (Scheme 2) by coordination of the enantiomerically pure ligand $\mathbf{5}(\mathrm{R})$, which was accessed according to Scheme 1 from the optically pure alcohol 3. Acetophenone was the chosen model for our hydrogenation studies, the catalysis being carried out under standard conditions (Scheme 4). In basic media, one could expect the deprotonation of the acidic proton on the sulfonamide inducing the conversion of 6,8 and 10 to 7,9 and 11 respectively. Following initial exploratory experiments, carried out with complex 6 at $50^{\circ} \mathrm{C}$ under $\mathrm{ATH}$ conditions (no $\mathrm{H}_{2}$ pressure), which reached only $10 \%$ conversion after 4 days, subsequent experiments were carried out either in the presence of hydrogen or at a higher temperature $\left(82^{\circ} \mathrm{C}\right)$ (the results are collected in Table 6). Under 30 bars of $\mathrm{H}_{2}$, significant 
conversion took place after 6 hours even at $50^{\circ} \mathrm{C}$. The best conversion was observed with the ruthenium complex 6, although without any significant ee. Complexes 8 and 10, on the other hand, gave lower conversions and better albeit still rather low ee. The experiments carried out at $82^{\circ} \mathrm{C}$ under transfer hydrogenation conditions gave almost full conversions after 5 hours with either $\mathrm{KOH}$ or $\mathrm{NaOH}$ when using complex 6, once again without notable enantioselectivity. A kinetic study yielded a first order decay for the substrate $\left(\mathrm{k}=0.650 \mathrm{~min}^{-1}\right)$ with $96 \%$ conversion after 5 hours (Figure 5$)$.

Scheme 4. Catalytic hydrogenation of acetophenone.

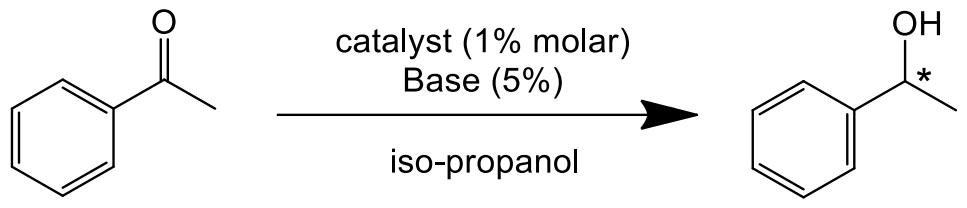

Table 6. Catalytic hydrogenation of acetophenone. ${ }^{\text {a }}$

\begin{tabular}{llllllll}
\hline entry & catalyst & $\mathrm{P}_{\mathrm{H} 2}$ (bar) & $\mathrm{T}\left({ }^{\circ} \mathrm{C}\right)$ & base & $\mathrm{t}(\mathrm{h})$ & conv. $(\%)$ & ee(\%) \\
\hline 1 & $\mathbf{6}$ & 30 & 50 & $\mathrm{NaOH}$ & 6 & 72 & 1 \\
2 & $\mathbf{8}$ & 30 & 50 & $\mathrm{NaOH}$ & 6 & 32 & 21 \\
3 & $\mathbf{1 0}$ & 30 & 50 & $\mathrm{NaOH}$ & 6 & 18 & 29 \\
4 & $\mathbf{6}$ & - & 82 & $\mathrm{KOH}$ & 5 & 99 & 5 \\
5 & $\mathbf{6}$ & - & 82 & $\mathrm{NaOH}$ & 5 & 97 & 6
\end{tabular}

${ }^{\mathrm{a}}$ All reactions were carried out with $0.5 \mathrm{mmol}$ acetophenone, $1 \%$ catalyst, $1.5 \mathrm{~mL} i \mathrm{PrOH}$, and 0.025 mmol base.
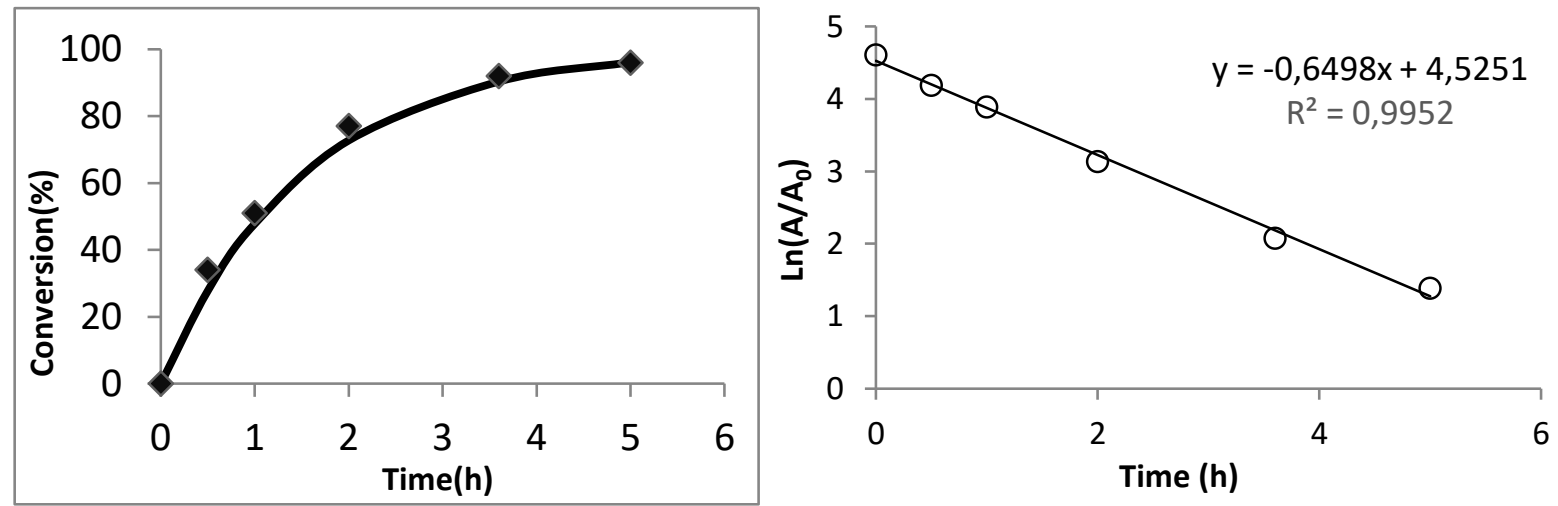
Figure 5. Kinetics investigation of the reaction of acetophenone $(0.5 \mathrm{mmol})$ in $5 \mathrm{~mL}$ iPrOH with $1 \%$ of catalyst $6(0.005 \mathrm{mmol})$ and $5 \%$ of $\mathrm{NaOH}(0.025 \mathrm{mmol})$ at $82^{\circ} \mathrm{C}$ : time dependence of conversion (left) and first order plot (right).

\section{Conclusions}

We have reported herein the synthesis and coordination study of the new chiral ferrocenyl aminophosphines 5 and 5a. A series of half sandwich ruthenium $(\mathbf{6})$, rhodium $(\mathbf{8}, \mathbf{8 a})$ and iridium (10) complexes bearing a monocoordinated neutral P,N ligand have been synthesized and fully characterized. The variable temperature NMR studies show dynamic behavior that, because of the very similar behavior of $\mathbf{8}$ and $\mathbf{8 a}$, cannot be attributed to the establishment of $\mathrm{H}$ bonds $(\mathrm{N}-\mathrm{H} \cdots \mathrm{Cl})$ that are visible in the solid state. The DFT study, while confirming the possible existence of isomeric complexes that differ by the presence and location of the $\mathrm{H}$ bond, indicates that these isomers should interconvert too rapidly to be individually detected on the NMR timescale. By default, the phenomenon is attributed to

restricted rotations around sterically crowded bonds. Deprotonation of complexes $\mathbf{6 , 8}$ and $\mathbf{1 0}$ at the sulfonamide function gives rise to the new complexes 7, 9 and $\mathbf{1 1}$, where the P-amido ligand is bonded to the metal as a bidentate anionic ligand.

Complexes 6, 8 and 10 show moderate catalytic activity for the hydrogenation or transfer hydrogenation of acetophenone by $\mathrm{H}_{2}$ or $i \mathrm{PrOH}$ at $50^{\circ} \mathrm{C}$. At higher temperature, complex 6 shows good catalytic activity in transfer hydrogenation. In both cases, the enationselectivity is poor. Although poor in terms of catalytic performance, these compounds may prove useful for mechanistic studies that are currently in progress. Coordination chemistry studies of these ligands on other catalytic platforms are also planned for the near future.

\section{Experimental Section}


General Considerations. All reactions were carried out using conventional Schlenk techniques under an inert atmosphere of argon. Thin layer chromatography and flash chromatography were carried out on Merck Kieselgel 60F254 precoated aluminum plates and Merck Kieselgel 60 respectively. Solvents were dried by conventional methods before use. Tetrafluoroboric acid diethylether complex (SigmaAldrich), $p$-toluenesulfonamide (Sigma-Aldrich) and tris(dimethylamino) phosphine (Alfa Aesar) were used as received without further purification. Racemic 2-thiodiphenylphosphino(hydroxymethyl)ferrocene, 1, was synthesized according to published procedure. ${ }^{[19]} \mathrm{GC}$ analyses were realized with an Agilent 5890 chromatograph equipped with FID detector and BETA DEX 225 chiral capillary column $(30 \mathrm{~m} / 0.25 \mathrm{~mm} / 0.25 \mu \mathrm{m})$. NMR analyses were performed on Bruker AV500 instruments. The spectra were referenced internally using the signal from the residual solvent for ${ }^{1} \mathrm{H}$ and ${ }^{13} \mathrm{C}$, and externally using $85 \% \mathrm{H}_{3} \mathrm{PO}_{4}$ for ${ }^{31} \mathrm{P}$. Chemical shifts and coupling constants are given in ppm and Hertz respectively. The following abbreviations are used: s: singlet; d: doublet; t: triplet; quint: quintuplet; m: multiplet; br: broad. Mass spectral analyses (GCT 1er Waters for DCI, CH4; UPLC Xevo G2 Q TOF (Waters) for $\mathrm{ES}^{+}$) were performed by "Service commun de spectrométrie de masse', of the Université Paul-Sabatier, Toulouse (France).

Synthesis and caraterization of compound 4. In a Schlenk tube, 3 (250 mg, $0.58 \mathrm{mmol})$ was dissolved in $5 \mathrm{~mL}$ of dry dichloromethane. A solution of tetrafluoroboric acid in ether $(250 \mu \mathrm{L}, 1.84$ mmol) was then added. After 1 min of stirring, a solution of $1.98 \mathrm{~g}$ of $p$-toluenesulfonamide (12 mmol) in $14 \mathrm{~mL}$ of dry dichloromethane was added. After 1 min of stirring, the crude product was separated by chromatography on silica gel with pentane/ether $(7 / 3 \mathrm{v} / \mathrm{v})$ as eluent. After evaporation of the solvent, $260 \mathrm{mg}$ of 4 were obtained (yellow solid, yield $=98 \%) .{ }^{1} \mathrm{H}\left\{{ }^{31} \mathrm{P}\right\} \mathrm{NMR}\left(500 \mathrm{MHz}, \mathrm{CDCl}_{3}\right) \delta(\mathrm{ppm})$ : $7.81\left(2 \mathrm{H}, \mathrm{m}, \mathrm{PPh}_{2}\right), 7.65\left(2 \mathrm{H}, \mathrm{m}, \mathrm{SO}_{2} \underline{\mathrm{PhCH}}_{3}\right), 7.58\left(1 \mathrm{H}, \mathrm{m}, \mathrm{PPh}_{2}\right), 7.54\left(2 \mathrm{H}, \mathrm{m}, \mathrm{PPh}_{2}\right), 7.52(2 \mathrm{H}, \mathrm{m}$,

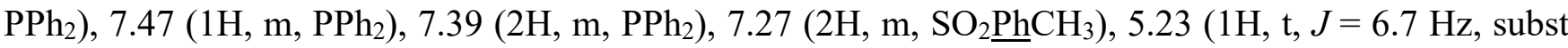
Cp), $4.61(1 \mathrm{H}$, br, subst Cp), $4.33(1 \mathrm{H}, \mathrm{s}, \mathrm{NH}), 4.30(5 \mathrm{H}, \mathrm{s}, \mathrm{Cp}), 3.89(1 \mathrm{H}, \mathrm{dd}, J=14.1 \mathrm{~Hz}, 6.7 \mathrm{~Hz}$, $\left.\mathrm{C}_{2} \mathrm{NH}\right), 3.86\left(1 \mathrm{H}, \mathrm{dd}, J=14.1 \mathrm{~Hz}, 6.7 \mathrm{~Hz}, \underline{\mathrm{C}}_{2} \mathrm{NH}\right), 3.77\left(1 \mathrm{H}\right.$, br, subst Cp), $2.44\left(3 \mathrm{H}, \mathrm{s}, \mathrm{SO}_{2} \mathrm{PhC}_{3}\right)$.

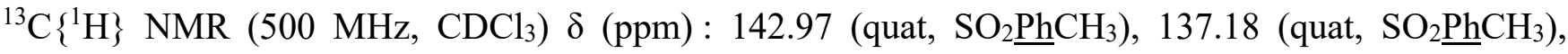


$135.05\left(J_{C P}=84.8 \mathrm{~Hz}\right.$, quat, $\left.\mathrm{PPh}_{2}\right), 132.74\left(J_{\mathrm{CP}}=84.8 \mathrm{~Hz}\right.$, quat, $\left.\mathrm{PPh}_{2}\right), 131.97\left(J_{C P}=10.6 \mathrm{~Hz}, \mathrm{PPh}_{2}\right)$, $131.72\left(J_{C P}=10.2 \mathrm{~Hz}, \mathrm{PPh}_{2}\right), 131.57\left(J_{\mathrm{CP}}=3.6 \mathrm{~Hz}, \mathrm{PPh}_{2}\right), 131.39\left(J_{C P}=3.6 \mathrm{~Hz}, \mathrm{PPh}_{2}\right), 129.52$

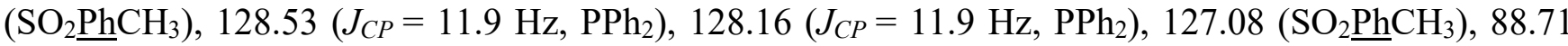
$\left(J_{C P}=11.8 \mathrm{~Hz}\right.$, quat, subst Cp), $74.88\left(J_{C P}=12.9 \mathrm{~Hz}\right.$, subst Cp), $74.67\left(J_{C P}=12.9 \mathrm{~Hz}\right.$, subst Cp), 73.94 $\left(J_{C P}=83.9 \mathrm{~Hz}\right.$, quat, subst $\left.\mathrm{Cp}\right), 70.75(\mathrm{Cp}), 69.28\left(J_{C P}=10.4 \mathrm{~Hz}\right.$, subst $\left.\mathrm{Cp}\right), 41.08\left(\mathrm{CH}_{2} \mathrm{NH}\right), 21.53$ $\left(\mathrm{SO}_{2} \mathrm{PhCH}_{3}\right) .{ }^{31} \mathrm{P}\left\{{ }^{1} \mathrm{H}\right\}$ NMR $\left(500 \mathrm{MHz}, \mathrm{CDCl}_{3}\right) \delta(\mathrm{ppm}): 41.10 . \mathrm{HR} / \mathrm{MS}\left(\mathrm{DCI}, \mathrm{CH}_{4}\right) \mathrm{m} / \mathrm{e}: 585.0649(\mathrm{M}$, 19\%) (calc. M: 585.0648).

Synthesis and caraterization of compound 5. In a Schlenk tube, $260 \mathrm{mg}$ of $4(0.46 \mathrm{mmol})$ were dissolved in $9.16 \mathrm{~mL}$ of dry toluene together with $0.5 \mathrm{~mL}$ of tris(dimethylamino)phosphine $(2.75$ mmol). The solution was kept at reflux overnight under argon. After cooling back to room temperature, the solution was evaporated under reduced pressure. The crude residue was purified under argon by flash chromatography on silica gel with dichloromethane as eluent. After evaporation of the solvent, $236.76 \mathrm{mg}$ of 5 were obtained (yellow solid, yield $=93 \%) .{ }^{1} \mathrm{H}\left\{{ }^{31} \mathrm{P}\right\} \mathrm{NMR}\left(500 \mathrm{MHz}, \mathrm{CDCl}_{3}\right) \delta(\mathrm{ppm})$ :

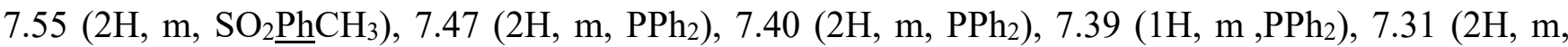
$\left.\mathrm{PPh}_{2}\right), 7.31\left(1 \mathrm{H}, \mathrm{m}, \mathrm{PPh}_{2}\right), 7.25\left(2 \mathrm{H}, \mathrm{m}, \mathrm{SO}_{2} \mathrm{PhCH}_{3}\right), 7.11\left(2 \mathrm{H}, \mathrm{m}, \mathrm{PPh}_{2}\right), 4.43(1 \mathrm{H}, \mathrm{dd}, J=4.3 \mathrm{~Hz}, 2.4$ Hz, subst Cp), $4.27(1 \mathrm{H}, \mathrm{t}, J=2.5 \mathrm{~Hz}$, subst Cp), $4.22(1 \mathrm{H}, \mathrm{t}, J=6.1 \mathrm{~Hz}, \mathrm{NH}), 4.07(5 \mathrm{H}, \mathrm{s}, \mathrm{Cp}), 4.00$ $\left(1 \mathrm{H}, \mathrm{dd}, J=13.2 \mathrm{~Hz}, 6.5 \mathrm{~Hz}, \underline{\mathrm{CH}}_{2} \mathrm{NH}\right), 3.98\left(1 \mathrm{H}, \mathrm{dd}, J=13.3 \mathrm{~Hz}, 5.1 \mathrm{~Hz}, \underline{\mathrm{CH}}_{2} \mathrm{NH}\right), 3.71(1 \mathrm{H}, \mathrm{dd}, J=$ $2.3 \mathrm{~Hz}, 1.1 \mathrm{~Hz}$, subst Cp), $2.44\left(3 \mathrm{H}, \mathrm{s}, \mathrm{SO}_{2} \mathrm{PhC}_{3}\right) .{ }^{13} \mathrm{C}\left\{{ }^{1} \mathrm{H}\right\} \mathrm{NMR}\left(500 \mathrm{MHz}, \mathrm{CDCl}_{3}\right) \delta(\mathrm{ppm}): 143.17$ (quat, $\mathrm{SO}_{2} \underline{\mathrm{PhCH}_{3}}$ ), $139.14\left(J_{C P}=10.4 \mathrm{~Hz}\right.$, quat, $\left.\mathrm{PPh}_{2}\right), 136.77$ (quat, $\left.\mathrm{SO}_{2} \underline{\mathrm{PhCH}_{3}}\right), 136.31\left(J_{C P}=8 \mathrm{~Hz}\right.$,

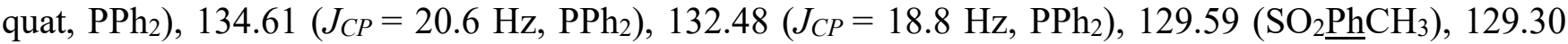
$\left(\mathrm{PPh}_{2}\right), 128.62\left(\mathrm{PPh}_{2}\right), 128.57\left(J_{C P}=6.3 \mathrm{~Hz}, \mathrm{PPh}_{2}\right), 128.29\left(J_{C P}=8 \mathrm{~Hz}, \mathrm{PPh}_{2}\right), 127.03\left(\mathrm{SO}_{2} \underline{\left.\mathrm{PhCH}_{3}\right),}\right.$ $87.93\left(J_{C P}=24.2 \mathrm{~Hz}\right.$, quat, subst Cp), $76.29\left(J_{C P}=7.0 \mathrm{~Hz}\right.$, quat, subst Cp), $72.07\left(J_{C P}=2.9 \mathrm{~Hz}\right.$, subst Cp), $71.62\left(J_{C P}=2.9 \mathrm{~Hz}\right.$, subst Cp), $69.73(\mathrm{Cp}), 69.70$ (subst Cp), $41.82\left(\mathrm{CH}_{2} \mathrm{NH}\right), 21.55\left(\mathrm{SO}_{2} \mathrm{PhCH}_{3}\right)$. ${ }^{31} \mathrm{P}\left\{{ }^{1} \mathrm{H}\right\}$ NMR $\left(500 \mathrm{MHz}, \mathrm{CDCl}_{3}\right) \delta(\mathrm{ppm}):-24.24$. HR/MS (DCI, $\left.\mathrm{CH}_{4}\right) \mathrm{m} / \mathrm{e}: 554.1006(\mathrm{M}+1,100 \%)$ (calc. $M+1: 554.0927)$ 
Synthesis and caraterization of compound 4a. In a Schlenk tube, $200 \mathrm{mg}$ of 3 (0.46 mmol) were dissolved in $4 \mathrm{~mL}$ of dry dichloromethane. A solution of tetrafluoroboric acid in ether $(200 \mu \mathrm{L}, 1.47$ mmol) was then added. After $1 \mathrm{~min}$ of stirring, a solution of $1.7 \mathrm{~g}$ of $N$-methyl- $p$-toluenesulfonamide $(9.26 \mathrm{mmol})$ in $10 \mathrm{~mL}$ of dry dichloromethane was added. After $1 \mathrm{~min}$ of stirring, the crude product was separated by chromatography on silica gel with pentane/ether $(7 / 3 \mathrm{v} / \mathrm{v})$ as eluent. After evaporation of the solvent, $275.8 \mathrm{mg}$ of $\mathbf{4 a}$ were obtained (yellow solid, yield $=100 \%) .{ }^{1} \mathrm{H}\left\{{ }^{31} \mathrm{P}\right\} \mathrm{NMR}(500 \mathrm{MHz}$, $\left.\mathrm{CDCl}_{3}\right) \delta(\mathrm{ppm}): 7.84\left(2 \mathrm{H}, \mathrm{m}, \mathrm{PPh}_{2}\right), 7.62\left(2 \mathrm{H}, \mathrm{m}, \mathrm{PPh}_{2}\right), 7.61\left(2 \mathrm{H}, \mathrm{m}, \mathrm{SO}_{2} \mathrm{PhCH}_{3}\right), 7.55\left(1 \mathrm{H}, \mathrm{m}, \mathrm{PPh}_{2}\right)$, $7.50\left(1 \mathrm{H}, \mathrm{m}, \mathrm{PPh}_{2}\right), 7.45\left(2 \mathrm{H}, \mathrm{m}, \mathrm{PPh}_{2}\right), 7.37\left(2 \mathrm{H}, \mathrm{m}, \mathrm{PPh}_{2}\right), 7.30\left(2 \mathrm{H}, \mathrm{m}, \mathrm{SO}_{2} \mathrm{PhCH}_{3}\right), 4.95(1 \mathrm{H}, \mathrm{m}$, subst Cp), $4.37(1 \mathrm{H}, \mathrm{t}, J=2.4 \mathrm{~Hz}$, subst $\mathrm{Cp}), 4.69\left(1 \mathrm{H}, \mathrm{d}, J=15.5 \mathrm{~Hz} \underline{\mathrm{H}}_{2} \mathrm{~N}\right), 4.35(5 \mathrm{H}, \mathrm{s}, \mathrm{Cp}), 4.29$ $\left(1 \mathrm{H}, \mathrm{d}, J=15.5 \mathrm{~Hz}, \underline{\mathrm{C}}_{2} \mathrm{~N}\right), 3.78(1 \mathrm{H}, \mathrm{br}$, subst $\mathrm{Cp}), 2.44\left(3 \mathrm{H}, \mathrm{s}, \mathrm{SO}_{2} \mathrm{PhCH}_{3}\right) .2 .38\left(3 \mathrm{H}, \mathrm{s}, \mathrm{NCH}_{3}\right)$.

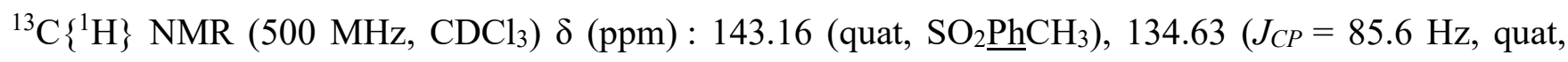

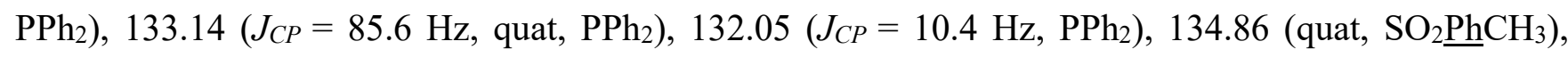
$131.99\left(J_{C P}=10.4 \mathrm{~Hz}, \mathrm{PPh}_{2}\right), 129.65\left(\mathrm{SO}_{2} \underline{\mathrm{PhCH}_{3}}\right), 131.41\left(J_{C P}=3.0 \mathrm{~Hz}, \mathrm{PPh}_{2}\right), 131.33\left(J_{C P}=3.0 \mathrm{~Hz}\right.$, $\left.\mathrm{PPh}_{2}\right), 128.32\left(J_{C P}=11.9 \mathrm{~Hz}, \mathrm{PPh}_{2}\right), 128.08\left(J_{C P}=11.9 \mathrm{~Hz}, \mathrm{PPh}_{2}\right), 127.38\left(\mathrm{SO}_{2} \underline{\mathrm{PhCH}_{3}}\right), 88.58\left(J_{C P}=\right.$ 11.5 Hz, quat, subst Cp), $73.77\left(J_{C P}=92.2 \mathrm{~Hz}\right.$, quat, subst Cp), $74.79\left(J_{C P}=8.9 \mathrm{~Hz}\right.$, subst Cp), 74.49 $\left(J_{C P}=12.1 \mathrm{~Hz}\right.$, subst Cp), $69.58\left(J_{C P}=10.4 \mathrm{~Hz}\right.$, subst Cp), $71.07(\mathrm{Cp}), 48.71\left(\mathrm{CH}_{2} \mathrm{~N}\right), 35.55\left(\mathrm{NCH}_{3}\right)$, $21.50\left(\mathrm{SO}_{2} \mathrm{PhCH}_{3}\right) .{ }^{31} \mathrm{P}\left\{{ }^{1} \mathrm{H}\right\} \mathrm{NMR}\left(500 \mathrm{MHz}, \mathrm{CDCl}_{3}\right) \delta(\mathrm{ppm}): 41.07 . \mathrm{HR} / \mathrm{MS}\left(\mathrm{ES}^{+}\right) \mathrm{m} / \mathrm{e}: 599.0820(\mathrm{M}$, 30\%) (calc. M: 599.0805); 622.0718 (M+Na, 100\%) (calc. $\mathrm{M}+\mathrm{Na}: 622.0703)$.

Synthesis and caraterization of compound 5a. In a Schlenk tube, $300 \mathrm{mg}$ of $\mathbf{4 a}(0.50 \mathrm{mmol})$ were dissolved in $9.8 \mathrm{~mL}$ of dry toluene together with $0.46 \mathrm{~mL}$ of tris(dimethylamino)phosphine $(2.51$ mmol). The solution was kept at reflux overnight under argon. After cooling back to room temperature, the solution was evaporated in vacuo. The crude residue was purified under argon by flash chromatography on silica gel with dichloromethane as eluent. After evaporation of the solvent, 283.8 mg of 5a were obtained (yellow solid, yield $=100 \%) .{ }^{1} \mathrm{H}\left\{{ }^{31} \mathrm{P}\right\} \mathrm{NMR}\left(500 \mathrm{MHz}, \mathrm{CDCl}_{3}\right) \delta(\mathrm{ppm}): 7.64$ $\left(2 \mathrm{H}, \mathrm{d}, \mathrm{J}=8.0 \mathrm{~Hz}, \mathrm{SO}_{2} \mathrm{PhCH}_{3}\right), 7.58\left(2 \mathrm{H}, \mathrm{m}, \mathrm{PPh}_{2}\right), 7.41\left(2 \mathrm{H}, \mathrm{m}, \mathrm{PPh}_{2}\right), 7.40\left(1 \mathrm{H}, \mathrm{t}, J=4.9 \mathrm{~Hz}_{2} \mathrm{PPh}_{2}\right)$,

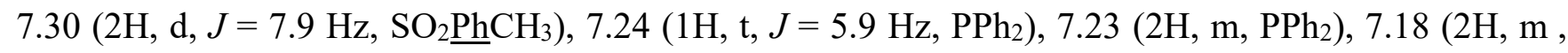


$\left.\mathrm{PPh}_{2}\right), 4.65(1 \mathrm{H}, \mathrm{dd}, J=2.5,1.2 \mathrm{~Hz}$, subst Cp), $4.37(1 \mathrm{H}, \mathrm{t}, J=2.5 \mathrm{~Hz}$, subst Cp), 4.03 (5H, s, Cp), 4.4 $\left(1 \mathrm{H}, \mathrm{d}, J=14.1 \mathrm{~Hz} \underline{\mathrm{H}}_{2} \mathrm{~N}\right), 4.12\left(1 \mathrm{H}, \mathrm{d}, J=14.1 \mathrm{~Hz}, \underline{\mathrm{C}}_{2} \mathrm{~N}\right), 3.90(1 \mathrm{H}, \mathrm{dd}, J=2.5,1.2 \mathrm{~Hz}$, subst Cp), $2.45\left(3 \mathrm{H}, \mathrm{s}, \mathrm{SO}_{2} \mathrm{PhCH}_{3}\right) .2 .32\left(3 \mathrm{H}, \mathrm{s}, \mathrm{NCH}_{3}\right) .{ }^{13} \mathrm{C}\left\{{ }^{1} \mathrm{H}\right\} \mathrm{NMR}\left(500 \mathrm{MHz}, \mathrm{CDCl}_{3}\right) \delta(\mathrm{ppm}): 143.10$ (quat, $\left.\mathrm{SO}_{2} \underline{\mathrm{PhCH}}_{3}\right), 139.52\left(\mathrm{~J}_{\mathrm{CP}}=8.9 \mathrm{~Hz}\right.$, quat, $\left.\mathrm{PPh}_{2}\right), 137.31\left(\mathrm{~J}_{\mathrm{CP}}=8.9 \mathrm{~Hz}\right.$, quat, $\left.\mathrm{PPh}_{2}\right), 135.03\left(\mathrm{~J}_{\mathrm{CP}}=21.5 \mathrm{~Hz}\right.$

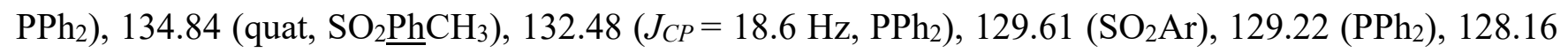
$\left(\mathrm{J}_{\mathrm{CP}}=8.2 \mathrm{~Hz}, \mathrm{PPh}_{2}\right), 128.06\left(J_{C P}=6.0 \mathrm{~Hz}, \mathrm{PPh}_{2}\right), 128.00\left(\mathrm{PPh}_{2}\right), 127.49\left(\mathrm{SO}_{2} \mathrm{Ar}\right), 88.18\left(J_{C P}=25.7 \mathrm{~Hz}\right.$ quat, subst Cp), $76.28\left(J_{C P}=9.7 \mathrm{~Hz}\right.$, quat, subst Cp), $73.07\left(J_{C P}=4.2 \mathrm{~Hz}\right.$, subst Cp), $71.81\left(J_{C P}=4.2\right.$ Hz, subst Cp), 70.22 (subst Cp), $69.91(\mathrm{Cp}), 48.50\left(J_{C P}=10.4 \mathrm{~Hz}, \mathrm{CH}_{2} \mathrm{~N}\right), 34.34\left(\mathrm{NCH}_{3}\right), 21.54$ $\left(\mathrm{SO}_{2} \mathrm{PhCH}_{3}\right) .{ }^{31} \mathrm{P}\left\{{ }^{1} \mathrm{H}\right\}$ NMR $\left(500 \mathrm{MHz}, \mathrm{CDCl}_{3}\right) \delta(\mathrm{ppm}):-25.37 . \mathrm{HR} / \mathrm{MS}\left(\mathrm{ES}^{+}\right) \mathrm{m} / \mathrm{e}: 568.1169(\mathrm{M}$, 100\%) (calc. M: 568.1162).

Synthesis and caraterization of compound 6. In a Schlenk tube under argon, a mixture of compound 5 (10 mg, $0.018 \mathrm{mmol})$ and $\left[\mathrm{Ru}(\mathrm{p} \text {-cymene }) \mathrm{Cl}_{2}\right]_{2}(5.53 \mathrm{mg}, 0.009 \mathrm{mmol})$ was dissolved in dry dichloromethane $(2 \mathrm{~mL})$. The reaction was carried under room temperature for one hour. The solvent was evaporated and the resulting red solid was washed by dry pentane. After evaporation of the solvent, $15.32 \mathrm{mg}$ of 6 were obtained (yield $=99 \%) .{ }^{1} \mathrm{H}\left\{{ }^{31} \mathrm{P}\right\}$ NMR $\left(500 \mathrm{MHz}, \mathrm{CDCl}_{3}\right) \delta(\mathrm{ppm}): 8.41(2 \mathrm{H}, \mathrm{m}$, $\left.\mathrm{PPh}_{2}\right), 7.92\left(2 \mathrm{H}, \mathrm{m}, \mathrm{PPh}_{2}\right), 7.61\left(2 \mathrm{H}, \mathrm{m}, \mathrm{SO}_{2} \mathrm{PhCH}_{3}\right), 7.47\left(3 \mathrm{H}, \mathrm{m}, \mathrm{PPh}_{2}\right), 7.29\left(1 \mathrm{H}, \mathrm{m}, \mathrm{PPh}_{2}\right), 7.28(2 \mathrm{H}$

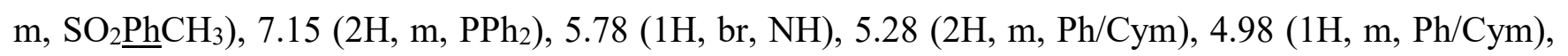
$4.86(1 \mathrm{H}, \mathrm{m}, \mathrm{Ph} / \mathrm{Cym}), 4.85(1 \mathrm{H}, \mathrm{s}$, subst $\mathrm{Cp}), 4.55(1 \mathrm{H}, \mathrm{s}$, subst $\mathrm{Cp}), 4.50(1 \mathrm{H}, \mathrm{s}$, subst $\mathrm{Cp}), 4.10(5 \mathrm{H}$, s, Cp), $3.41\left(1 \mathrm{H}, \mathrm{dd}, J=13.4 \mathrm{~Hz}, 8.4 \mathrm{~Hz}, \mathrm{C}_{2} \mathrm{NH}\right), 2.72\left(1 \mathrm{H}, \mathrm{dd}, J=13.7 \mathrm{~Hz}, 3.5 \mathrm{~Hz}, \mathrm{C}_{2} \mathrm{NH}\right), 2.66$ (1H, heptuplet, $\left.J=6.9 \mathrm{~Hz}, \underline{\mathrm{CH}}\left(\mathrm{CH}_{3}\right)_{2}\right), 2.47\left(3 \mathrm{H}, \mathrm{s}, \mathrm{SO}_{2} \mathrm{PhCH}_{3}\right), 1.68\left(3 \mathrm{H}, \mathrm{s}, \mathrm{PhCH}_{3} / \mathrm{Cym}\right), 1.03(3 \mathrm{H}, \mathrm{d}$, $\left.\mathrm{J}=6.9 \mathrm{~Hz}, \mathrm{CH}\left(\mathrm{C}_{3}\right)_{2}\right), 0.91\left(3 \mathrm{H}, \mathrm{d}, J=6.9 \mathrm{~Hz}, \mathrm{CH}\left(\mathrm{C}_{3}\right)_{2}\right) .{ }^{13} \mathrm{C}\left\{{ }^{1} \mathrm{H}\right\} \mathrm{NMR}\left(500 \mathrm{MHz}, \mathrm{CDCl}_{3}\right) \delta$

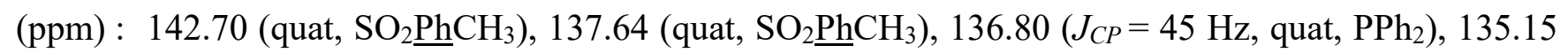
$\left(J_{C P}=9.5 \mathrm{~Hz}, \mathrm{PPh}_{2}\right), 133.58\left(J_{C P}=9.5 \mathrm{~Hz}, \mathrm{PPh}_{2}\right), 131.91\left(J_{C P}=45 \mathrm{~Hz}\right.$, quat, $\left.\mathrm{PPh}_{2}\right), 130.49\left(J_{C P}=2.1\right.$

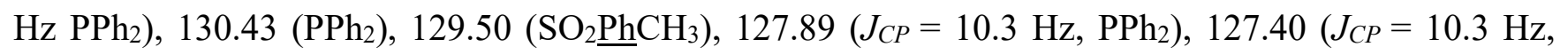
$\mathrm{PPh}_{2}$ ), $127.06\left(\mathrm{SO}_{2} \underline{\mathrm{PhCH}_{3}}\right.$ ), 110.74 (quat, $\left.\mathrm{Ph} / \mathrm{Cym}\right), 94.23$ (quat, $\left.\mathrm{Ph} / \mathrm{Cym}\right), 92.73(\mathrm{Ph} / \mathrm{Cym}), 89.10$ $(\mathrm{Ph} / \mathrm{Cym}), 87.49\left(J_{C P}=7.6 \mathrm{~Hz}, \mathrm{Ph} / \mathrm{Cym}\right), 86.50\left(J_{C P}=7.6 \mathrm{~Hz}\right.$, quat, subst Cp), $83.82(\mathrm{Ph} / \mathrm{Cym}), 78.39$ 
$\left(J_{C P}=38.2 \mathrm{~Hz}\right.$, quat, subst Cp), $76.10\left(J_{C P}=14.3 \mathrm{~Hz}\right.$, subst Cp $), 73.31\left(J_{C P}=7.2 \mathrm{~Hz}\right.$, subst Cp $), 71.03$

$(\mathrm{Cp}), 70.22\left(J_{C P}=8.3 \mathrm{~Hz}\right.$, subst $\left.\mathrm{Cp}\right), 40.85\left(\mathrm{CH}_{2} \mathrm{NH}\right), 30.10(\mathrm{CH} / \mathrm{Cym}), 22.23\left(\mathrm{CH}^{2} \mathrm{H}_{3} / \mathrm{Cym}\right)$, 21.55( $\left(\mathrm{SO}_{2} \mathrm{PhCH}_{3}\right), 21.17\left(\mathrm{CHCH}_{3} / \mathrm{Cym}\right), 17.18\left(\mathrm{PhCH}_{3} / \mathrm{Cym}\right) .{ }^{31} \mathrm{P}\left\{{ }^{1} \mathrm{H}\right\} \mathrm{NMR}\left(500 \mathrm{MHz}, \mathrm{CDCl}_{3}\right) \delta$ (ppm): 14.60. HR/MS (ES ${ }^{+}$m/e: 824.0756 (M-Cl, 70\%) (calc. M-Cl: 824.0755).

Synthesis and caraterization of compound 7. In a Schlenk tube under argon, compound 6 (15.47 $\mathrm{mg}, 0.018 \mathrm{mmol})$ was dissolved in dry dichloromethane $(2 \mathrm{~mL})$ and then triethylamine $(12.54 \mu \mathrm{l}, 0.09$ mmol) was added. The reaction was carried under at $40^{\circ} \mathrm{C}$ for 1.5 hour. The solvent was evaporated and the resulting red solid was washed by dry pentane. After evaporation of the solvent, $11.87 \mathrm{mg}$ of 7 were obtained (yield $=80 \%)$. First diastereoisomer ${ }^{1} \mathrm{H}\left\{{ }^{31} \mathrm{P}\right\}$ NMR $\left(500 \mathrm{MHz}, \mathrm{CDCl}_{3}\right) \delta(\mathrm{ppm}): 8.50-7.20$

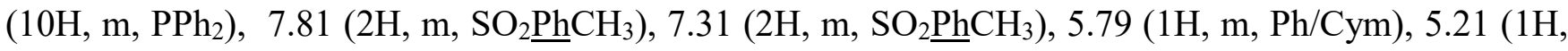
d, $\left.J=15.3 \mathrm{~Hz}, \mathrm{CH}_{2} \mathrm{~N}\right), 5.15(1 \mathrm{H}, \mathrm{m}, \mathrm{Ph} / \mathrm{Cym}), 4.89(1 \mathrm{H}, \mathrm{m}, \mathrm{Ph} / \mathrm{Cym}), 4.74(1 \mathrm{H}, \mathrm{m}, \mathrm{Ph} / \mathrm{Cym}), 4.39(1 \mathrm{H}$, br, subst Cp), $4.10(1 \mathrm{H}$, br, subst $\mathrm{Cp}), 4.09\left(1 \mathrm{H}, \mathrm{d}, J=17.8 \mathrm{~Hz}, \mathrm{CH}_{2} \mathrm{~N}\right), 3.99(1 \mathrm{H}$, br, subst Cp), 3.67 (5H, s, Cp), $2.95\left(1 \mathrm{H}\right.$, heptuplet, $\left.J=7.2 \mathrm{~Hz}, \mathrm{C} \underline{\mathrm{H}}\left(\mathrm{CH}_{3}\right)_{2}\right), 2.45\left(3 \mathrm{H}, \mathrm{s}, \mathrm{SO}_{2} \mathrm{PhC}_{3}\right), 1.27(3 \mathrm{H}, \mathrm{d}, J=6.2$ $\left.\mathrm{Hz}, \mathrm{CH}\left(\mathrm{C}_{3}\right)_{2}\right), 1.24\left(3 \mathrm{H}, \mathrm{d}, J=6.2 \mathrm{~Hz}, \mathrm{CH}\left(\mathrm{C}_{3}\right)_{2}\right), 0.56\left(3 \mathrm{H}, \mathrm{s}, \mathrm{PhCH}_{3} / \mathrm{Cym}\right) .{ }^{13} \mathrm{C}\left\{{ }^{1} \mathrm{H}\right\} \mathrm{NMR}(500$ $\left.\mathrm{MHz}, \mathrm{CDCl}_{3}\right) \delta(\mathrm{ppm}): 143.09$ (quat, $\mathrm{SO}_{2} \mathrm{PhCH}_{3}$ ), 140.59 (quat, $\left.\mathrm{SO}_{2} \mathrm{PhCH}_{3}\right), 138.80\left(\mathrm{~J}_{\mathrm{CP}}=49.1 \mathrm{~Hz}\right.$, quat, $\left.\mathrm{PPh}_{2}\right), 132.52\left(J_{C P}=8 \mathrm{~Hz}, \mathrm{PPh}_{2}\right), 131.07\left(\mathrm{PPh}_{2}\right), 129.60\left(\mathrm{PPh}_{2}\right), 129.49\left(J_{C P}=13.2 \mathrm{~Hz}, \mathrm{PPh}_{2}\right)$, $129.49\left(\mathrm{SO}_{2} \underline{\mathrm{PhCH}_{3}}\right), 128.07\left(J_{C P}=10.4 \mathrm{~Hz}, \mathrm{PPh}_{2}\right), 127.3\left(J_{C P}=8.9 \mathrm{~Hz}, \mathrm{PPh}_{2}\right), 126.55\left(\mathrm{SO}_{2} \underline{\mathrm{PhCH}_{3}}\right)$, 124.88 (quat, $\mathrm{Ph} / \mathrm{Cym}), 98.94\left(J_{C P}=13.6 \mathrm{~Hz}\right.$, quat, subst $\mathrm{Cp}$ ), $98.53(\mathrm{Ph} / \mathrm{Cym}), 92.78$ (quat, $\left.\mathrm{Ph} / \mathrm{Cym}\right)$, $85.45(\mathrm{Ph} / \mathrm{Cym}), 83.18(\mathrm{Ph} / \mathrm{Cym}), 75.11(\mathrm{Ph} / \mathrm{Cym}), 70.54(\mathrm{Cp}), 70.1\left(J_{C P}=49.2 \mathrm{~Hz}\right.$, subst $\left.\mathrm{Cp}\right), 69.09$ $\left(\mathrm{J}_{\mathrm{CP}}=7.7 \mathrm{~Hz}\right.$, subst Cp), 68.13 (subst Cp), $44.81\left(\mathrm{CH}_{2} \mathrm{~N}\right), 31.13(\mathrm{CH} / \mathrm{Cym}), 23.70\left(\mathrm{CHCH}_{3} / \mathrm{Cym}\right), 21.68$ $\left(\mathrm{SO}_{2} \mathrm{Ph}_{\underline{C}} \mathrm{H}_{3}\right), 12.61\left(\mathrm{PhCH}_{3} / \mathrm{Cym}\right) .{ }^{31} \mathrm{P}\left\{{ }^{1} \mathrm{H}\right\} \quad \mathrm{NMR}(500 \mathrm{MHz}, \mathrm{CDCl} 3) \delta$ (ppm): 18.31. Second diastereoisomer ${ }^{1} \mathrm{H}\left\{{ }^{31} \mathrm{P}\right\}$ NMR $\left(500 \mathrm{MHz}, \mathrm{CDCl}_{3}\right) \delta(\mathrm{ppm}): 8.50-7.20\left(10 \mathrm{H}, \mathrm{m}, \mathrm{PPh}_{2}\right), 7.89(2 \mathrm{H}, \mathrm{m}$, $\left.\mathrm{SO}_{2} \underline{\mathrm{PhCH}}_{3}\right), 7.31\left(2 \mathrm{H}, \mathrm{m}, \mathrm{SO}_{2} \underline{\mathrm{PhCH}}_{3}\right), 5.57(1 \mathrm{H}, \mathrm{m}, \mathrm{Ph} / \mathrm{Cym}), 5.24(1 \mathrm{H}, \mathrm{m}, \mathrm{Ph} / \mathrm{Cym}), 4.59(1 \mathrm{H}, \mathrm{m}$, $\mathrm{Ph} / \mathrm{Cym}), 4.44\left(1 \mathrm{H}, \mathrm{d}, J=23 \mathrm{~Hz}, \mathrm{CH}_{2} \mathrm{~N}\right), 4.36\left(1 \mathrm{H}, \mathrm{d}, J=38.8 \mathrm{~Hz}, \mathrm{CH}_{2} \mathrm{~N}\right), 4.22(1 \mathrm{H}, \mathrm{m}, \mathrm{Ph} / \mathrm{Cym}), 4.16$ $(1 \mathrm{H}, \mathrm{t}, J=2.5 \mathrm{~Hz}$, subst $\mathrm{Cp}), 4.10(1 \mathrm{H}$, br, subst $\mathrm{Cp}), 4.04(1 \mathrm{H}$, br, subst $\mathrm{Cp}), 3.53(5 \mathrm{H}, \mathrm{s}, \mathrm{Cp}), 2.63$ (1H, heptuplet, $\left.J=7.4 \mathrm{~Hz}, \mathrm{C} \underline{\mathrm{H}}\left(\mathrm{CH}_{3}\right)_{2}\right), 2.45\left(3 \mathrm{H}, \mathrm{s}, \mathrm{SO}_{2} \mathrm{PhC}_{3}\right), 1.91\left(3 \mathrm{H}, \mathrm{s}, \mathrm{PhCH}_{3} / \mathrm{Cym}\right), 0.98(3 \mathrm{H}, \mathrm{d}$, 
$\left.\mathrm{J}=6.8 \mathrm{~Hz}, \mathrm{CH}\left(\mathrm{C}_{3}\right)_{2}\right), 0.94\left(3 \mathrm{H}, \mathrm{d}, J=6.8 \mathrm{~Hz}, \mathrm{CH}\left(\mathrm{C}_{3}\right)_{2}\right) .{ }^{13} \mathrm{C}\left\{{ }^{1} \mathrm{H}\right\} \mathrm{NMR}\left(500 \mathrm{MHz}, \mathrm{CDCl}_{3}\right) \delta(\mathrm{ppm}):$

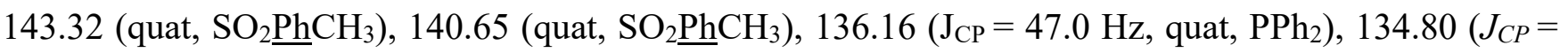
47.0 Hz, quat, $\left.\mathrm{PPh}_{2}\right), 131.46\left(J_{C P}=9.9 \mathrm{~Hz}, \mathrm{PPh}_{2}\right), 131.15\left(\mathrm{PPh}_{2}\right), 129.91\left(\mathrm{PPh}_{2}\right), 129.44\left(J_{C P}=12.7 \mathrm{~Hz}\right.$, $\left.\mathrm{PPh}_{2}\right), 128.19\left(\mathrm{SO}_{2} \mathrm{PhCH}_{3}\right), 128.15\left(J_{C P}=9.8 \mathrm{~Hz}, \mathrm{PPh}_{2}\right), 127.33\left(J_{C P}=9.5 \mathrm{~Hz}, \mathrm{PPh}_{2}\right), 126.48$ $\left(\mathrm{SO}_{2} \mathrm{PhCH}_{3}\right), 118.34$ (quat, $\left.\mathrm{Ph} / \mathrm{Cym}\right), 89.85$ (Ph/Cym), 96.97 (quat, $\left.\mathrm{Ph} / \mathrm{Cym}\right), 84.90$ (Ph/Cym), 84.31 $(\mathrm{Ph} / \mathrm{Cym}), 87.53(\mathrm{Ph} / \mathrm{Cym}), 95.99\left(J_{C P}=12.4 \mathrm{~Hz}\right.$, quat, subst $\mathrm{Cp}$ ), 70.06 (subst $\left.\mathrm{Cp}\right), 70.42(\mathrm{Cp}), 66.56$ $\left(J_{C P}=6.6 \mathrm{~Hz}\right.$, subst $\left.\mathrm{Cp}\right), 67.91\left(J_{C P}=4.5 \mathrm{~Hz}\right.$, subst $\left.\mathrm{Cp}\right), 47.67\left(\mathrm{CH}_{2} \mathrm{~N}\right), 30.24(\mathrm{CH} / \mathrm{Cym}), 22.98$ $\left(\mathrm{CH}_{\underline{C}} \mathrm{H}_{3} / \mathrm{Cym}\right), 21.68\left(\mathrm{SO}_{2} \mathrm{PhCH}_{3}\right), 20.46\left(\mathrm{CH}^{2} \mathrm{H}_{3} / \mathrm{Cym}\right), 19.55\left(\mathrm{PhCH}_{3} / \mathrm{Cym}\right) .{ }^{31} \mathrm{P}\left\{{ }^{1} \mathrm{H}\right\} \mathrm{NMR}(500$ $\mathrm{MHz}, \mathrm{CDCl} 3) \delta(\mathrm{ppm}): 26.56 . \mathrm{HR} / \mathrm{MS}\left(\mathrm{ES}^{+}\right) \mathrm{m} / \mathrm{e}: 824.0768\left(\mathrm{M}+\mathrm{H}^{+}, 30 \%\right)\left(\right.$ calc. $\mathrm{M}+\mathrm{H}^{+}:$824.0755).

Synthesis and caraterization of compound 8. In a Schlenk tube under argon, a mixture of compound $5(10 \mathrm{mg}, 0.018 \mathrm{mmol})$ and $\left[\mathrm{RhCp}^{*} \mathrm{Cl}_{2}\right]_{2}(5.56 \mathrm{mg}, 0.009 \mathrm{mmol})$ was dissolved in dry dichloromethane $(2 \mathrm{~mL})$. The reaction was carried under room temperature for one hour. The solvent was evaporated and the resulting red solid was washed by dry pentane. After evaporation of the solvent, $15.35 \mathrm{mg}$ of 8 were obtained (yield $=99 \%) .{ }^{1} \mathrm{H}\left\{{ }^{31} \mathrm{P}\right\} \mathrm{NMR}\left(500 \mathrm{MHz}, \mathrm{CDCl}_{3}\right) \delta(\mathrm{ppm}): 8.32(2 \mathrm{H}, \mathrm{m}$, $\left.\mathrm{PPh}_{2}\right), 7.95\left(2 \mathrm{H}, \mathrm{m}, \mathrm{PPh}_{2}\right), 7.60\left(2 \mathrm{H}, \mathrm{m}, \mathrm{SO}_{2} \underline{\mathrm{PhCH}_{3}}\right), 7.54\left(1 \mathrm{H}, \mathrm{m}, \mathrm{PPh}_{2}\right), 7.48\left(2 \mathrm{H}, \mathrm{m}, \mathrm{PPh}_{2}\right), 7.47(1 \mathrm{H}$, m, $\left.\mathrm{PPh}_{2}\right), 7.35\left(2 \mathrm{H}, \mathrm{m}, \mathrm{PPh}_{2}\right), 7.34\left(2 \mathrm{H}, \mathrm{m}, \mathrm{SO}_{2} \underline{\mathrm{PhCH}_{3}}\right), 5.69(1 \mathrm{H}, \mathrm{br}, \mathrm{NH}), 4.96(1 \mathrm{H}, \mathrm{s}$, subst $\mathrm{Cp}), 4.47$ (1H, s, subst Cp), $4.28\left(1 \mathrm{H}, \mathrm{s}\right.$, subst Cp), $3.97(5 \mathrm{H}, \mathrm{s}, \mathrm{Cp}), 3.37\left(1 \mathrm{H}, \mathrm{dd}, J=13.8 \mathrm{~Hz}, 8.3 \mathrm{~Hz}, \mathrm{C}_{2} \mathrm{NH}\right)$, $2.75\left(1 \mathrm{H}, \mathrm{dd}, J=10.5 \mathrm{~Hz}, 4.1 \mathrm{~Hz}, \underline{\mathrm{C}}_{2} \mathrm{NH}\right), 2.51\left(3 \mathrm{H}, \mathrm{s}, \mathrm{SO}_{2} \mathrm{PhC}_{3}\right), 1.28(15 \mathrm{H}, \mathrm{s}, \mathrm{Cp} *) .{ }^{13} \mathrm{C}\left\{{ }^{1} \mathrm{H}\right\} \mathrm{NMR}$ $\left(500 \mathrm{MHz}, \mathrm{CDCl}_{3}\right) \delta(\mathrm{ppm}): 143.03$ (quat, $\mathrm{SO}_{2} \underline{\mathrm{PhCH}_{3}}$ ), 137.77 (quat, $\mathrm{SO}_{2} \underline{\left.\mathrm{PhCH}_{3}\right)}, 135.21\left(J_{C P}=5.9\right.$ $\left.\mathrm{Hz}, \mathrm{PPh}_{2}\right), 134.38\left(\mathrm{~J}_{\mathrm{CP}}=10 \mathrm{~Hz}, \mathrm{PPh}_{2}\right), 133.11\left(\mathrm{~J}_{\mathrm{CP}}=43 \mathrm{~Hz}\right.$, quat, $\left.\mathrm{PPh}_{2}\right), 131.00\left(\mathrm{~J}_{\mathrm{CP}}=2.1 \mathrm{~Hz} \mathrm{PPh}_{2}\right)$,

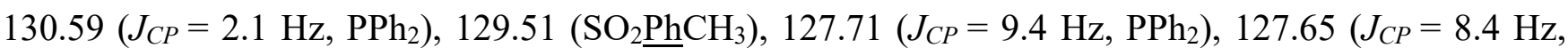
$\left.\mathrm{PPh}_{2}\right), 127.03\left(\mathrm{SO}_{2} \underline{\mathrm{PhCH}_{3}}\right), 99.13\left(J_{C P}=2.8\right.$, quat, $\left.\mathrm{CCH}_{3} / \mathrm{Cp}^{*}\right), 86.31\left(J_{C P}=5.3 \mathrm{~Hz}\right.$, quat, subst $\left.\mathrm{Cp}\right)$, $77.68\left(J_{C P}=17.8 \mathrm{~Hz}\right.$, subst Cp), $75.99\left(J_{C P}=41.9 \mathrm{~Hz}\right.$, quat, subst Cp), $72.74\left(J_{C P}=4.5 \mathrm{~Hz}\right.$, subst Cp $)$, $70.70(\mathrm{Cp}), 69.68\left(J_{C P}=9.3 \mathrm{~Hz}\right.$, subst $\left.\mathrm{Cp}\right), 41.19\left(\mathrm{CH}_{2} \mathrm{NH}\right), 21.23\left(\mathrm{SO}_{2} \mathrm{PhCH}_{3}\right), 8.44\left(\mathrm{CH}_{3} / \mathrm{Cp}^{*}\right)$. ${ }^{31} \mathrm{P}\left\{{ }^{1} \mathrm{H}\right\}$ NMR $\left(500 \mathrm{MHz}, \mathrm{CDCl}_{3}\right) \delta(\mathrm{ppm}): 24.20(\mathrm{~d}, J=133.67 \mathrm{~Hz}) . \mathrm{HR} / \mathrm{MS}\left(\mathrm{DCI}, \mathrm{CH}_{4}\right) \mathrm{m} / \mathrm{e}$ : $790.1078\left(\mathrm{M}-\mathrm{HCl}_{2}, 100 \%\right)$ (cals. M-HCl $2:$ 790.1078). 
Synthesis and caraterization of compound 8a. In a Schlenk tube under argon, a mixture of compound 5a $(10 \mathrm{mg}, 0.018 \mathrm{mmol})$ and $\left[\mathrm{RhCp}^{*} \mathrm{Cl}_{2}\right]_{2}(5.56 \mathrm{mg}, 0.009 \mathrm{mmol})$ was dissolved in dry dichloromethane $(2 \mathrm{~mL})$. The reaction was carried under room temperature for one hour. The solvent was evaporated and the resulting red solid was washed by dry pentane. After evaporation of the solvent, $13.07 \mathrm{mg}$ of $8 \mathbf{a}$ were obtained (yield $=83 \%) .{ }^{1} \mathrm{H}\left\{{ }^{31} \mathrm{P}\right\} \mathrm{NMR}\left(500 \mathrm{MHz}, \mathrm{CDCl}_{3}\right) \delta(\mathrm{ppm}): 8.36(2 \mathrm{H}, \mathrm{m}$,

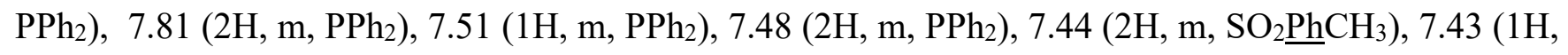

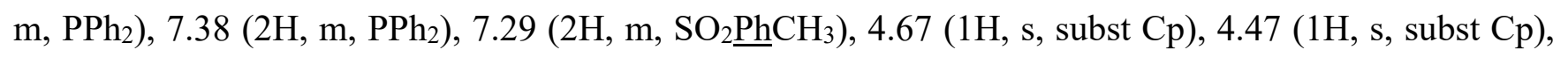
$4.22\left(1 \mathrm{H}, \mathrm{s}\right.$, subst Cp), 3.99 (5H, s, Cp), $3.62\left(1 \mathrm{H}, \mathrm{d}, J=15.5 \mathrm{~Hz}, \mathrm{CH}_{2} \mathrm{NH}\right), 3.35(1 \mathrm{H}, \mathrm{d}, J=15.5 \mathrm{~Hz}$ $\left.\mathrm{C}_{2} \mathrm{NH}\right), 2.54\left(3 \mathrm{H}, \mathrm{s}, \mathrm{NCH}_{3}\right), 2.47\left(3 \mathrm{H}, \mathrm{s}, \mathrm{SO}_{2} \mathrm{PhCH}_{3}\right), 1.27(15 \mathrm{H}, \mathrm{s}, \mathrm{Cp} *) .{ }^{13} \mathrm{C}\left\{{ }^{1} \mathrm{H}\right\} \mathrm{NMR}(500 \mathrm{MHz}$ $\left.\mathrm{CDCl}_{3}\right) \delta(\mathrm{ppm}): 143.16$ (quat, $\mathrm{SO}_{2} \underline{\mathrm{PhCH}_{3}}$ ), 134.37 (quat, $\mathrm{SO}_{2} \underline{\mathrm{PhCH}_{3}}$ ), $135.43\left(J_{C P}=7.0 \mathrm{~Hz}, \mathrm{PPh}_{2}\right.$ ), 134.38 $\left(\mathrm{PPh}_{2}\right), 133.71\left(\right.$ quat, $\left.\mathrm{PPh}_{2}\right), 131.56\left(\right.$ quat, $\left.\mathrm{PPh}_{2}\right), 130.57\left(J_{C P}=2.7 \mathrm{~Hz} \mathrm{PPh}_{2}\right), 130.39\left(J_{C P}=2.7\right.$

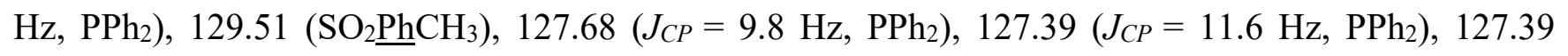

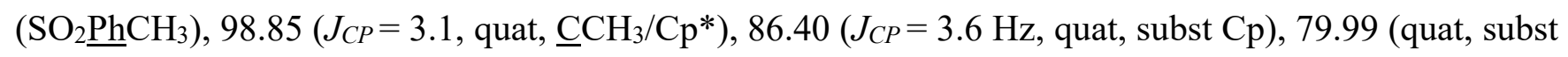
Cp), $71.82\left(\mathrm{~J}_{\mathrm{CP}}=5.3 \mathrm{~Hz}\right.$, subst Cp), 70.52 (subst Cp), $71.43(\mathrm{Cp}), 68.35\left(J_{C P}=9.1 \mathrm{~Hz}\right.$, subst Cp), 50.22 $\left(\mathrm{CH}_{2} \mathrm{NH}\right), 35.72\left(\mathrm{NCH}_{3}\right), 21.50\left(\mathrm{SO}_{2} \mathrm{PhCH}_{3}\right), 8.59\left(\mathrm{CH}_{3} / \mathrm{Cp}^{*}\right) .{ }^{31} \mathrm{P}\left\{{ }^{1} \mathrm{H}\right\} \mathrm{NMR}\left(500 \mathrm{MHz}, \mathrm{CDCl}_{3}\right) \delta$ (ppm): $23.10(\mathrm{~d}, J=145.83 \mathrm{~Hz}) . \mathrm{HR} / \mathrm{MS}\left(\mathrm{DCI}, \mathrm{CH}_{4}\right) \mathrm{m} / \mathrm{e}: 840.1002(\mathrm{M}-\mathrm{Cl}, 100 \%)$ (calc. M-Cl: 840.1002).

Synthesis and caraterization of compound 9. In a Schlenk tube under argon, compound 8 (15.56 $\mathrm{mg}, 0.018 \mathrm{mmol})$ was dissolved in dry dichloromethane $(2 \mathrm{~mL})$ and then triethylamine $(12.54 \mu 1,0.09$ mmol) was added. The reaction was carried under room temperature for one night. The solvent was evaporated and the resulting red solid was washed by dry pentane. After evaporation of the solvent, $11.29 \mathrm{mg}$ of 9 were obtained (yield $=76 \%)$. First diastereoisomer ${ }^{1} \mathrm{H}\left\{{ }^{31} \mathrm{P}\right\} \mathrm{NMR}\left(500 \mathrm{MHz}, \mathrm{CDCl}_{3}\right) \delta$ (ppm) : $8.41\left(2 \mathrm{H}, \mathrm{m}, \mathrm{PPh}_{2}\right), 7.86\left(2 \mathrm{H}, \mathrm{m}, \mathrm{SO}_{2} \underline{\mathrm{PhCH}}_{3}\right), 7.80\left(2 \mathrm{H}, \mathrm{m}, \mathrm{PPh}_{2}\right), 7.71\left(2 \mathrm{H}, \mathrm{m}, \mathrm{PPh}_{2}\right), 7.65$ $\left(1 \mathrm{H}, \mathrm{m}, \mathrm{PPh}_{2}\right), 7.41\left(1 \mathrm{H}, \mathrm{m}, \mathrm{PPh}_{2}\right), 7.34\left(2 \mathrm{H}, \mathrm{m}, \mathrm{PPh}_{2}\right), 7.25\left(2 \mathrm{H}, \mathrm{m}, \mathrm{SO}_{2} \mathrm{PhCH}_{3}\right), 4.44(1 \mathrm{H}, \mathrm{d}, J=16.0$ $\left.\mathrm{Hz}, \mathrm{CH}_{2} \mathrm{~N}\right), 4.14(1 \mathrm{H}, \mathrm{dd}, J=2.3,1.1 \mathrm{~Hz}$, subst $\mathrm{Cp}), 4.09(1 \mathrm{H}, \mathrm{t}, J=2.4 \mathrm{~Hz}$, subst Cp), $3.95(1 \mathrm{H}, \mathrm{d}, J=$ $\left.15.7 \mathrm{~Hz}, \mathrm{CH}_{2} \mathrm{~N}\right), 3.93\left(1 \mathrm{H}, \mathrm{dd}, J=1.9,1.0 \mathrm{~Hz}\right.$, subst Cp), $3.56(5 \mathrm{H}, \mathrm{s}, \mathrm{Cp}), 2.40\left(3 \mathrm{H}, \mathrm{s}, \mathrm{SO}_{2} \mathrm{PhC}_{3}\right)$, 
$1.21(15 \mathrm{H}, \mathrm{s}, \mathrm{Cp} *) .{ }^{13} \mathrm{C}\left\{{ }^{1} \mathrm{H}\right\} \mathrm{NMR}\left(500 \mathrm{MHz}, \mathrm{CDCl}_{3}\right) \delta$ (ppm): 144.26 (quat, $\mathrm{SO}_{2} \mathrm{PhCH}_{3}$ ), 140.00 (quat, $\left.\mathrm{SO}_{2} \underline{\mathrm{PhCH}_{3}}\right), 136.30\left(J_{C P}=11.7 \mathrm{~Hz}, \mathrm{PPh}_{2}\right), 134.0\left(J_{C P}=7 \mathrm{~Hz}, \mathrm{PPh}_{2}\right), 133.19\left(J_{C P}=47.0 \mathrm{~Hz}\right.$, quat, $\left.\mathrm{PPh}_{2}\right)$, $132.96\left(J_{C P}=50.0 \mathrm{~Hz}\right.$, quat, $\left.\mathrm{PPh}_{2}\right), 131.41\left(\mathrm{PPh}_{2}\right), 130.21\left(\mathrm{PPh}_{2}\right), 129.05\left(\mathrm{SO}_{2} \mathrm{PhCH}_{3}\right), 128.29\left(J_{C P}=\right.$ $\left.11.4 \mathrm{~Hz}, \mathrm{PPh}_{2}\right), 126.85\left(J_{C P}=9.8 \mathrm{~Hz}, \mathrm{PPh} 2\right), 126.75\left(\mathrm{SO}_{2} \underline{\mathrm{PhCH}_{3}}\right), 100.50\left(J_{C P}=3.2 \mathrm{~Hz}\right.$, quat,

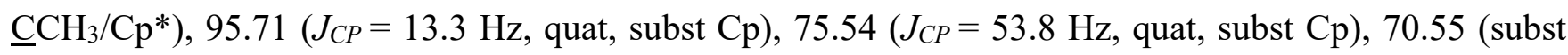
Cp), 70.33(Cp), $67.90\left(J_{C P}=8.0 \mathrm{~Hz}\right.$, subst $\left.\mathrm{Cp}\right), 65.89\left(J_{C P}=8.0 \mathrm{~Hz}\right.$, subst $\left.\mathrm{Cp}\right), 47.09\left(\mathrm{CH}_{2} \mathrm{~N}\right), 21.38$ $\left(\mathrm{SO}_{2} \mathrm{PhCH}_{3}\right), 9.38\left(\mathrm{CCH}_{3} / \mathrm{Cp}^{*}\right) .{ }^{31} \mathrm{P}\left\{{ }^{1} \mathrm{H}\right\} \mathrm{NMR}(500 \mathrm{MHz}, \mathrm{CDCl} 3) \delta(\mathrm{ppm}): 30.93(\mathrm{~d}, J=142.8 \mathrm{~Hz})$. ${ }^{103} \mathrm{Rh}\left\{{ }^{31} \mathrm{P}\right\}$ NMR $\left(500 \mathrm{MHz}, \mathrm{CDCl}_{3}\right) \delta(\mathrm{ppm}):-6263$. Second diastereoisomer. ${ }^{1} \mathrm{H}\left\{{ }^{31} \mathrm{P}\right\}$ NMR $(500$ $\left.\mathrm{MHz}, \mathrm{CDCl}_{3}\right) \delta(\mathrm{ppm}):{ }^{1} \mathrm{H}\left\{{ }^{31} \mathrm{P}\right\} \mathrm{NMR}\left(500 \mathrm{MHz}, \mathrm{CDCl}_{3}\right) \delta(\mathrm{ppm}): 8.32\left(2 \mathrm{H}, \mathrm{m}, \mathrm{PPh}_{2}\right), 7.75(2 \mathrm{H}, \mathrm{m}$, $\left.\mathrm{SO}_{2} \mathrm{PhCH}_{3}\right), 7.65\left(2 \mathrm{H}, \mathrm{m}, \mathrm{PPh}_{2}\right), 7.65\left(2 \mathrm{H}, \mathrm{m}, \mathrm{PPh}_{2}\right), 7.64\left(1 \mathrm{H}, \mathrm{m}, \mathrm{PPh}_{2}\right), 7.38\left(2 \mathrm{H}, \mathrm{m}, \mathrm{PPh}_{2}\right), 7.34(1 \mathrm{H}$, m, $\left.\mathrm{PPh}_{2}\right), 7.23\left(2 \mathrm{H}, \mathrm{m}, \mathrm{SO}_{2} \underline{\mathrm{PhCH}}_{3}\right), 5.19\left(1 \mathrm{H}, \mathrm{d}, J=15.4 \mathrm{~Hz}, \underline{\mathrm{C}}_{2} \mathrm{~N}\right), 4.30(1 \mathrm{H}, \mathrm{dd}, \mathrm{J}=2.1 \mathrm{~Hz}, 1.1 \mathrm{~Hz}$, subst Cp), $4.06(1 \mathrm{H}, \mathrm{t}, J=2.5 \mathrm{~Hz}$, subst Cp), $3.91(1 \mathrm{H}, \mathrm{dd}, J=2.3,1.0 \mathrm{~Hz}$, subst Cp), $3.73(5 \mathrm{H}, \mathrm{s}, \mathrm{Cp})$, $3.63\left(1 \mathrm{H}, \mathrm{d}, J=15.7 \mathrm{~Hz}, \underline{\mathrm{C}}_{2} \mathrm{~N}\right), 2.40\left(3 \mathrm{H}, \mathrm{s}, \mathrm{SO}_{2} \mathrm{PhC}_{3}\right), 1.26\left(15 \mathrm{H}, \mathrm{s}, \mathrm{Cp} *{ }^{*}{ }^{13} \mathrm{C}\left\{{ }^{1} \mathrm{H}\right\} \mathrm{NMR}(500\right.$ $\left.\mathrm{MHz}, \mathrm{CDCl}_{3}\right) \delta(\mathrm{ppm}): 144.92$ (quat, $\mathrm{SO}_{2} \underline{\mathrm{PhCH}}_{3}$ ), 140.00 (quat, $\mathrm{SO}_{2} \underline{\mathrm{PhCH}_{3}}$ ), $135.89\left(J_{C P}=10.7 \mathrm{~Hz}\right.$, $\left.\underline{\mathrm{PPh}}_{2}\right), 135.79\left(J_{C P}=48.1 \mathrm{~Hz}\right.$, quat, $\left.\underline{\mathrm{Ph}}_{2}\right), 132.80\left(J_{C P}=50.7 \mathrm{~Hz}\right.$, quat, $\left.\mathrm{P} \underline{\mathrm{Ph}} 2\right), 132.71\left(\mathrm{~J}_{\mathrm{CP}}=8.9 \mathrm{~Hz}\right.$, $\mathrm{PPh} 2), 131.47\left(\underline{\mathrm{PPh}}_{2}\right), 129.79\left(\underline{\mathrm{Ph}}_{2}\right), 129.04\left(\mathrm{SO}_{2} \mathrm{Ar}\right), 128.23\left(J_{C P}=10.0 \mathrm{~Hz}, \mathrm{PPh} 2\right), 127.67\left(J_{C P}=9.8\right.$ $\left.\mathrm{Hz}, \underline{\mathrm{Ph}}_{2}\right), 126.34\left(\mathrm{SO}_{2} \underline{\mathrm{PhCH}}_{3}\right), 100.55\left(J_{C P}=2.5 \mathrm{~Hz}\right.$, quat, $\left.\underline{\mathrm{CCH}}_{3} / \mathrm{Cp}^{*}\right), 98.64\left(J_{C P}=13.2 \mathrm{~Hz}\right.$, quat, subst Cp), $71.78\left(J_{C P}=49.3 \mathrm{~Hz}\right.$, quat, subst $\mathrm{Cp}$ ), $70.43(\mathrm{Cp}), 69.63$ (subst Cp), $69.00\left(J_{C P}=7.9 \mathrm{~Hz}\right.$, subst $\mathrm{Cp}), 68.05\left(J_{C P}=6.5 \mathrm{~Hz}\right.$, subst $\left.\mathrm{Cp}\right), 45.49\left(\underline{\mathrm{CH}}_{2} \mathrm{~N}\right), 21.38\left(\mathrm{SO}_{2} \mathrm{Ph}_{\underline{C}} \mathrm{H}_{3}\right), 9.18\left(\mathrm{C}_{\mathrm{CH}} / \mathrm{Cp}^{*}\right){ }^{31} \mathrm{P}\left\{{ }^{1} \mathrm{H}\right\} \mathrm{NMR}$ $\left(500 \mathrm{MHz}, \mathrm{CDCl}_{3}\right) \delta(\mathrm{ppm}): 19.61(\mathrm{~d}, J=147.0 \mathrm{~Hz}){ }^{103} \mathrm{Rh}\left\{{ }^{31} \mathrm{P}\right\} \mathrm{NMR}\left(500 \mathrm{MHz}, \mathrm{CDCl}_{3}\right) \delta(\mathrm{ppm}):-$ 6179. HR/MS (DCI, $\mathrm{CH}_{4}$ ) m/e: 790.1078 (M-Cl, 50\%) (calc. M-Cl: 790.1078).

Synthesis and caraterization of compound 10. In a Schlenk tube under argon, a mixture of compound $5(10 \mathrm{mg}, 0.018 \mathrm{mmol})$ and $\left[\mathrm{IrCp}^{*} \mathrm{Cl}_{2}\right]_{2}(7.17 \mathrm{mg}, 0.009 \mathrm{mmol})$ was dissolved in dry dichloromethane $(2 \mathrm{~mL})$. The reaction was carried under room temperature for one night. The solvent was evaporated and the resulting yellow solid was washed by dry pentane. After evaporation of the solvent, $16.94 \mathrm{mg}$ of $\mathbf{1 0}$ were obtained (yield $=99 \%) .{ }^{1} \mathrm{H}\left\{{ }^{31} \mathrm{P}\right\} \operatorname{NMR}\left(500 \mathrm{MHz}, \mathrm{CDCl}_{3}\right) \delta(\mathrm{ppm}): 8.32$ 
$\left(2 \mathrm{H}, \mathrm{m}, \mathrm{PPh}_{2}\right), 7.85\left(2 \mathrm{H}, \mathrm{m}, \mathrm{PPh}_{2}\right), 7.60\left(2 \mathrm{H}, \mathrm{m}, \mathrm{SO}_{2} \mathrm{PhCH}_{3}\right), 7.47\left(1 \mathrm{H}, \mathrm{m}, \mathrm{PPh}_{2}\right), 7.42\left(2 \mathrm{H}, \mathrm{m}, \mathrm{PPh}_{2}\right)$,

$7.44\left(1 \mathrm{H}, \mathrm{m}, \mathrm{PPh}_{2}\right), 7.37\left(2 \mathrm{H}, \mathrm{m}, \mathrm{PPh}_{2}\right), 7.28\left(2 \mathrm{H}, \mathrm{m}, \mathrm{SO}_{2} \mathrm{PhCH}_{3}\right), 5.10(1 \mathrm{H}, \mathrm{br}, \mathrm{NH}), 5.05(1 \mathrm{H}, \mathrm{s}$, subst

Cp), $4.41(1 \mathrm{H}, \mathrm{s}$, subst Cp), $4.28(1 \mathrm{H}, \mathrm{s}$, subst Cp), $3.92(5 \mathrm{H}, \mathrm{s}, \mathrm{Cp}), 3.38(1 \mathrm{H}, \mathrm{dd}, J=14.2,6.2 \mathrm{~Hz}$,

$\left.\underline{\mathrm{C}}_{2} \mathrm{NH}\right), 3.01\left(1 \mathrm{H}, \mathrm{dd}, J=10.6,4.6 \mathrm{~Hz}, \underline{\mathrm{CH}}_{2} \mathrm{NH}\right), 2.47\left(3 \mathrm{H}, \mathrm{s}, \mathrm{SO}_{2} \mathrm{PhC}_{3}\right), 1.27(15 \mathrm{H}, \mathrm{s}, \mathrm{Cp} *){ }^{13} \mathrm{C}\left\{{ }^{1} \mathrm{H}\right\}$

NMR (500 MHz, $\left.\mathrm{CDCl}_{3}\right) \delta(\mathrm{ppm}): 142.68$ (quat, $\mathrm{SO}_{2} \mathrm{Ar}$ ), 137.63 (quat, $\mathrm{SO}_{2} \mathrm{Ar}$ ), $134.71\left(J_{C P}=9.9 \mathrm{~Hz}\right.$, $\left.\mathrm{PPh}_{2}\right), 134.52\left(J_{C P}=9.9 \mathrm{~Hz}, \mathrm{PPh}_{2}\right), 133.04\left(J_{C P}=55.2 \mathrm{~Hz}\right.$, quat, $\left.\mathrm{PPh}_{2}\right), 131.41\left(J_{C P}=55.2 \mathrm{~Hz}\right.$, quat, $\left.\mathrm{PPh}_{2}\right), 130.84\left(J_{C P}=2.0 \mathrm{~Hz}, \mathrm{PPh}_{2}\right), 130.57\left(J_{C P}=2.6 \mathrm{~Hz}, \mathrm{PPh}_{2}\right), 129.46\left(\mathrm{SO}_{2} \mathrm{Ar}\right), 127.68\left(J_{C P}=9.5 \mathrm{~Hz}\right.$, $\left.\mathrm{PPh}_{2}\right), 127.50\left(J_{C P}=10.4 \mathrm{~Hz}, \mathrm{PPh}_{2}\right), 127.15\left(\mathrm{SO}_{2} \mathrm{Ar}\right), 92.63\left(J_{C P}=2.5 \mathrm{~Hz}\right.$, quat, $\left.\underline{\mathrm{CCH}}_{3} / \mathrm{Cp}^{*}\right), 86.11\left(J_{C P}\right.$ $=5.5 \mathrm{~Hz}$, quat, subst Cp), $78.84\left(J_{C P}=19.7 \mathrm{~Hz}\right.$, subst Cp), $75.76\left(J_{C P}=51.2 \mathrm{~Hz}\right.$, quat, subst Cp), 72.64 $\left(J_{C P}=6.3 \mathrm{~Hz}\right.$, subst Cp), $70.65(\mathrm{Cp}), 69.29\left(J_{C P}=9.5 \mathrm{~Hz}\right.$, subst Cp), $41.42\left(\mathrm{CH}_{2} \mathrm{NH}\right), 21.47$ $\left(\mathrm{SO}_{2} \mathrm{PhCH}_{3}\right), 8.1\left(\mathrm{CH}_{3} / \mathrm{Cp}^{*}\right){ }^{31} \mathrm{P}\left\{{ }^{1} \mathrm{H}\right\} \mathrm{NMR}\left(500 \mathrm{MHz}, \mathrm{CDCl}_{3}\right) \delta(\mathrm{ppm}):-7.0 . \mathrm{HR} / \mathrm{MS}\left(\mathrm{ES}^{+}\right): 916.1400$ (M-Cl, 35\%) (calc. M-Cl: 916.1419).

Synthesis and caraterization of compound 11. In a Schlenk tube under argon, compound 10 (17.17 $\mathrm{mg}, 0.018 \mathrm{mmol})$ was dissolved in dry dichloromethane $(2 \mathrm{~mL})$ and then triethylamine $(12.54 \mu 1,0.09$ mmol) was added. The reaction was carried under room temperature for one night. The solvent was evaporated and the resulting yellow solid was washed by dry pentane. After evaporation of the solvent, $12.84 \mathrm{mg}$ of 11 were obtained (yield $=78 \%)$. First diastereoisomer ${ }^{1} \mathrm{H}\left\{{ }^{31} \mathrm{P}\right\} \mathrm{NMR}\left(500 \mathrm{MHz}, \mathrm{CDCl}_{3}\right) \delta$

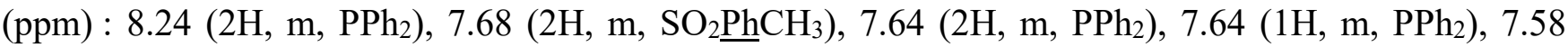
$\left(2 \mathrm{H}, \mathrm{m}, \mathrm{PPh}_{2}\right), 7.36\left(2 \mathrm{H}, \mathrm{m}, \mathrm{PPh}_{2}\right), 7.29\left(1 \mathrm{H}, \mathrm{m}, \mathrm{PPh}_{2}\right), 7.23\left(2 \mathrm{H}, \mathrm{m}, \mathrm{SO}_{2} \underline{\mathrm{PhCH}_{3}}\right), 5.64(1 \mathrm{H}, \mathrm{d}, J=15.4$ $\left.\mathrm{Hz}, \mathrm{CH}_{2} \mathrm{~N}\right), 4.33(1 \mathrm{H}$, br, subst Cp), $4.04(1 \mathrm{H}, \mathrm{t}, J=2.3 \mathrm{~Hz}$, subst $\mathrm{Cp}), 3.89(1 \mathrm{H}$, br, subst Cp), 3.78 $\left(1 \mathrm{H}, \mathrm{d}, J=15.4 \mathrm{~Hz}, \mathrm{CH}_{2} \mathrm{~N}\right), 3.73(5 \mathrm{H}, \mathrm{s}, \mathrm{Cp}), 2.40\left(3 \mathrm{H}, \mathrm{s}, \mathrm{SO}_{2} \mathrm{PhC}_{3}\right), 1.26(15 \mathrm{H}, \mathrm{s}, \mathrm{Cp} *) .{ }^{13} \mathrm{C}\left\{{ }^{1} \mathrm{H}\right\}$

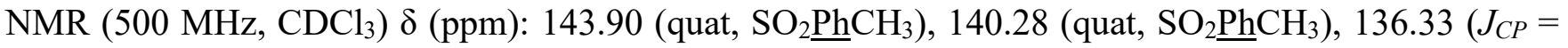
56.4 Hz, quat, $\left.\mathrm{PPh}_{2}\right), 135.83\left(J_{C P}=11.7 \mathrm{~Hz}, \mathrm{PPh}_{2}\right), 132.53\left(J_{C P}=8.8 \mathrm{~Hz}, \mathrm{PPh}_{2}\right), 131.41\left(\mathrm{PPh}_{2}\right), 129.61$

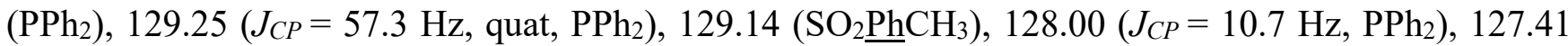
$\left(J_{C P}=10.7 \mathrm{~Hz}, \mathrm{PPh}_{2}\right), 126.28\left(\mathrm{SO}_{2} \underline{\mathrm{PhCH}_{3}}\right), 97.98\left(J_{C P}=11.6 \mathrm{~Hz}\right.$, quat, subst Cp), $94.32\left(J_{C P}=2.8 \mathrm{~Hz}\right.$, quat, $\left.\underline{\mathrm{CCH}} 3 / \mathrm{Cp}^{*}\right), 71.35\left(J_{C P}=57.6 \mathrm{~Hz}\right.$, quat, subst Cp), 70.34(Cp), 69.91 (subst Cp), $69.19\left(J_{C P}=7.9\right.$ 
$\mathrm{Hz}$, subst Cp), $67.81\left(J_{C P}=6.6 \mathrm{~Hz}\right.$, subst $\left.\mathrm{Cp}\right), 45.16\left(\mathrm{CH}_{2} \mathrm{~N}\right), 21.38\left(\mathrm{SO}_{2} \mathrm{PhCH}_{3}\right), 8.68\left(\mathrm{C}_{\mathrm{CH}} / \mathrm{Cp}^{*}\right)$.

${ }^{31} \mathrm{P}\left\{{ }^{1} \mathrm{H}\right\}$ NMR $\left(500 \mathrm{MHz}, \mathrm{CDCl}_{3}\right) \delta(\mathrm{ppm}):-10.13$ (s). Second diastereoisomer. ${ }^{1} \mathrm{H}\left\{{ }^{31} \mathrm{P}\right\}$ NMR $(500$

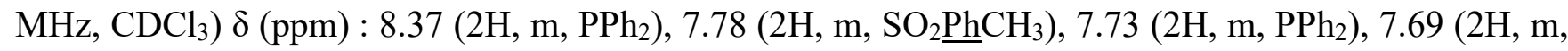
$\left.\mathrm{PPh}_{2}\right), 7.61\left(1 \mathrm{H}, \mathrm{m}, \mathrm{PPh}_{2}\right), 7.36\left(1 \mathrm{H}, \mathrm{m}, \mathrm{PPh}_{2}\right), 7.33\left(2 \mathrm{H}, \mathrm{m}, \mathrm{PPh}_{2}\right), 7.23\left(2 \mathrm{H}, \mathrm{m}, \mathrm{SO}_{2} \mathrm{PhCH}_{3}\right), 4.61(1 \mathrm{H}$, d, $\left.J=15.2 \mathrm{~Hz}, \mathrm{CH}_{2} \mathrm{~N}\right), 4.17(1 \mathrm{H}$, br, subst $\mathrm{Cp}), 4.09(1 \mathrm{H}, \mathrm{t}, J=2.2 \mathrm{~Hz}$, subst Cp), 3.92 (1H, br, subst Cp), $3.88\left(1 \mathrm{H}, \mathrm{d}, \mathrm{J}=15.0 \mathrm{~Hz}, \mathrm{CH}_{2} \mathrm{~N}\right), 3.58$ (5H, s, Cp), 2.40 (3H, s, $\left.\mathrm{SO}_{2} \mathrm{PhC}_{3}\right), 1.21$ (15H, s, Cp*). ${ }^{13} \mathrm{C}\left\{{ }^{1} \mathrm{H}\right\} \mathrm{NMR}\left(500 \mathrm{MHz}, \mathrm{CDCl}_{3}\right) \delta(\mathrm{ppm}): 143.90$ (quat, $\mathrm{SO}_{2} \underline{\mathrm{PhCH}_{3}}$ ), 140.36 (quat, $\mathrm{SO}_{2} \underline{\mathrm{PhCH}_{3}}$ ), $136.40\left(\mathrm{~J}_{\mathrm{CP}}=13.0 \mathrm{~Hz}, \mathrm{PPh}_{2}\right), 133.98\left(J_{C P}=8.0 \mathrm{~Hz}, \mathrm{PPh}_{2}\right), 133.12\left(J_{C P}=57.5 \mathrm{~Hz}\right.$, quat, $\left.\mathrm{PPh}_{2}\right), 132.51$

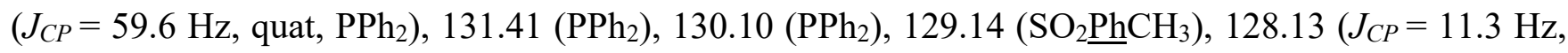

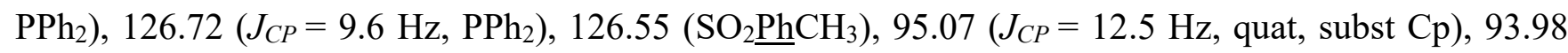

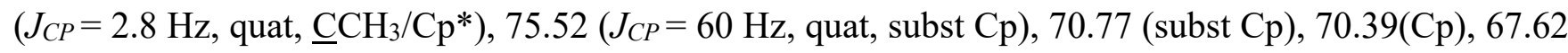
$\left(J_{C P}=7.6 \mathrm{~Hz}\right.$, subst Cp), $65.88\left(J_{C P}=8.2 \mathrm{~Hz}\right.$, subst Cp), $46.98\left(\mathrm{CH}_{2} \mathrm{~N}\right), 21.38\left(\mathrm{SO}_{2} \mathrm{PhCH}_{3}\right), 8.92$ $\left(\mathrm{CCH}_{3} / \mathrm{Cp}^{*}\right) .{ }^{31} \mathrm{P}\left\{{ }^{1} \mathrm{H}\right\}$ NMR $\left(500 \mathrm{MHz}, \mathrm{CDCl}_{3}\right) \delta(\mathrm{ppm}):-0.89$ (s). HR/MS (DCI, $\left.\mathrm{CH}_{4}\right): 880.1653(\mathrm{M}-$ $\mathrm{Cl}, 33 \%$ ) (calc. M-Cl: 880.1652).

Catalysis experiments. For the kinetic study: the catalyst $(0.005 \mathrm{mmol})$ and acetophenone $(0.5$ mmol) were dissolved in distilled $i \mathrm{PrOH}(4.75 \mathrm{~mL})$. After adding a $0.1 \mathrm{M} \mathrm{NaOH}$ solution in $i \mathrm{PrOH}$ $(0.25 \mathrm{~mL}, 0.025 \mathrm{mmol})$, the mixture was stirred at $82^{\circ} \mathrm{C}$. At various times, aliquots were withdrawn from the sample and passed through a short silica gel column before being analyzed by GC on a chiral column. For the transfer hydrogenation studies: the catalyst $(0.005 \mathrm{mmol})$ and acetophenone $(0.5$ mmol) were dissolved in distilled $i \mathrm{PrOH}(1.25 \mathrm{~mL})$. After introducing a $0.1 \mathrm{M}$ base $(\mathrm{NaOH}$ or $\mathrm{KOH})$ solution in $i \operatorname{PrOH}(0.25 \mathrm{~mL}, 0.025 \mathrm{mmol})$, the mixture was stirred at $82^{\circ} \mathrm{C}$. After 5 hours, the mixture was passed through a short silica gel column before being analyzed by GC on a chiral column. For the hydrogenation studies: the catalyst $(0.005 \mathrm{mmol})$ and acetophenone $(0.5 \mathrm{mmol})$ were dissolved in distilled $i \operatorname{PrOH}(1.25 \mathrm{~mL})$ in an autoclave. After addition of a $0.1 \mathrm{M} \mathrm{NaOH}$ solution in $i \operatorname{PrOH}(0.25 \mathrm{~mL}$, $0.025 \mathrm{mmol})$, the autoclave was pressurized by $\mathrm{H}_{2}\left(30\right.$ bar). The mixture was then stirred at $50^{\circ} \mathrm{C}$. After 
6 hours, the autoclave was cooled and vented and the recovered mixture was passed through a short silica gel column before being analyzed by GC on a chiral column.

X-ray structural analyses. A single crystal of each compound was mounted under inert perfluoropolyether at the tip of a glass fiber and cooled in the cryostream of either an OxfordDiffraction XCALIBUR CCD diffractometer for $\mathbf{4}$ and $\mathbf{6}$, or an Agilent Technologies GEMINI EOS diffractometer for $\mathbf{8 , ~ 8 a , ~} 10$ and 11. The structures were solved by direct methods (SIR97) ${ }^{36}$ and refined by least-squares procedures on $F^{2}$ using SHELXL-97. ${ }^{37}$ All $\mathrm{H}$ atoms attached to carbon atoms were introduced in the calculation at idealised positions and treated as riding models. In compound 8a, owing to the poor quality of the data, some residual electron density was difficult to model. Therefore, the SQUEEZE function of PLATON ${ }^{38}$ was used to eliminate the contribution of the electron density in the solvent region from the intensity data, and the solvent-free model was employed for the final refinement. There are two large cavities of $769 \AA^{3}$ per unit cell. PLATON estimated that each cavity contains about 138 electrons which may correspond to a mixture of dichloromethane and diethyl ether in the ratio one to two. Both solvents were used to crystallize the compound. The drawing of the molecules was realised with the help of ORTEP32 $2^{39}$ or PLATON. ${ }^{38}$ Crystal data and refinement parameters are available in the Supporting Information (Part 6).

Crystallographic data (excluding structure factors) for the structures reported in this paper have been deposited with the Cambridge Crystallographic Data Centre as supplementary publication no. CCDC6893066 (4), CCDC- 6893067 (6), CCDC-6893068 (8), CCDC-6893069 (8a), CCDC-6893070 (10), and CCDC-6893071 (11). Copies of the data can be obtained free of charge on application to CCDC, 12 Union Road, Cambridge CB2 IEZ, UK [Fax: int. Code +44(1223)336-033; E-mail: deposit@ccdc.cam.ac.uk].

Computational details. All calculations were carried out at the DFT level by means of the dispersion-corrected functional M06 as implemented in the Gaussian09 program package. ${ }^{40} \mathrm{Ir}, \mathrm{Fe}, \mathrm{Rh}$ and $\mathrm{Ru}$ atoms were described using the LANL2DZ effective core potential ${ }^{41,42}$ for the inner electrons and its associated double- $\zeta$ basis set for the outer ones. Additionally, f-polarization shells (exponents $=$ 
$0.938,2.462,1.350,1.235$, respectively ${ }^{43}$ were also added for these metal atoms. For $\mathrm{C}, \mathrm{O}, \mathrm{S}, \mathrm{P}, \mathrm{H}$ and the $\mathrm{Cl}$ and $\mathrm{N}$ atoms the $6-31 \mathrm{G}(\mathrm{d}, \mathrm{p})$ and the $6-31+\mathrm{G}(\mathrm{d})$ basis sets were used, respectively. Geometries of all the metal complexes were fully optimized without any symmetry constraint. Harmonic force constants were computed at the optimized geometries confirming the nature of these stationary points as minima. Solvent effects $\left(\mathrm{CH}_{2} \mathrm{Cl}_{2}, \varepsilon=8.930\right)$ were introduced through single point calculations at optimized gas-phase geometries by means of a continuum method, the SMD solvation model ${ }^{44}$ implemented in Gaussian09. The relative Gibbs energies in dichloromethane $\left(\Delta G_{\text {sol }}\right)$ were obtained by employing the following scheme:

$$
\Delta G_{\mathrm{sol}}=\Delta E_{\mathrm{sol}}+\left(\Delta G_{\mathrm{gas}}-\Delta E_{\mathrm{gas}}\right)
$$

The energies presented in this work are given in $\mathrm{kcal} / \mathrm{mol}$.

\section{ASSOCIATED CONTENT}

Supporting Information. Figures of optimized structures, tables of X-ray data, tables of selected bond distances and angles, Figures of NMR and HR mass spectra for all new compounds, table of Cartesian coordinates for all optimized structures (35 pages). This material is available free of charge via the Internet at http://pubs.acs.org.

\section{AUTHOR INFORMATION}

\section{Corresponding Author}

E-mail addresses: eric.deydier@iut-tlse3.fr, eric.manoury@1cc-toulouse.fr.

\section{Author Contributions}

The manuscript was written through contributions of all authors. All authors have given approval to the final version of the manuscript.

\section{Funding Sources}


Centre National de la Recherche Scientifique (CNRS) and Institut Universitaire de France (IUF).

\section{ACKNOWLEDGMENT}

We gratefully acknowledge financial support from the Centre National de la Recherche Scientifique

(CNRS), from the Institut Universitaire de France and the funding of Laboratoire Européen Associé «Laboratoire Trans-Pyrénéen: de la Molécule aux Matériaux » for the DFT calculation at Universitat Autònoma de Barcelona.

\section{REFERENCES}

(1) Phosphorus ligands in asymmetric catalysis; Börner, A., Ed.; Wiley-VCH: Weinheim, Germany, 2008; Vol. 1-3.

(2) Phosphorus compounds: advanced tools in catalysis and material science; Peruzzini, M.; Gonsalvi, L., Eds.; Springer: Dordrecht, 2011.

(3) Guiry, P. J.; Saunders, C. P. Advanced Synthesis \& Catalysis 2004, 346, 497-537.

(4) Börner, A. In Phosphorus ligands in asymmetric catalysis; Wiley-VCH: Weinheim, 2008 ; Vol. 2, p 549-629.

(5) Ganter, C. Chem. Soc. Rev. 2003, 32, 130-138.

(6) Brunner, H.; Kollnberger, A.; Mehmood, A.; Tsuno, T.; Zabel, M. J. Organomet. Chem. 2004, 689, 4244-4262.

(7) Gladiali, S.; Alberico, E. Chem. Soc. Rev. 2006, 35, 226-236.

(8) Ikariya, T.; Blacker, A. J. Acc. Chem. Res. 2007, 40, 1300-1308.

(9) Wu, X. F.; Xiao, J. L. Chem. Commun. 2007, 2449-2466.

(10) Wang, C.; Wu, X. F.; Xiao, J. L. Chem. Asian J. 2008, 3, 1750-1770.

(11) Wu, X. F.; Wang, C.; Xiao, J. L. Platinum Metals Review 2010, 54, 3-19.

(12) Lundgren, R. J.; Rankin, M. A.; Mcdonald, R.; Schatte, G.; Stradiotto, M. Angew. Chem. Engl. 2007, 46, 4732-4735.

(13) Onodera, G.; Nishibayashi, Y.; Uemura, S. Angew. Chem. Engl. 2006, 45, 3819-3822.

(14) Arikawa, Y.; Ueoka, M.; Matoba, K.; Nishibayashi, Y.; Hidai, M.; Uemura, S. J. Organomet. Chem. 1999, 572, 163-168.

(15) Nishibayashi, Y.; Takei, I.; Uemura, S.; Hidai, M. Organometallics 1999, 18, 2291-2293.

(16) Hounjet, L. J.; Ferguson, M. J.; Cowie, M. Organometallics 2011, 30, 4108-4114.

(17) Bacchi, A.; Balordi, M.; Cammi, R.; Elviri, L.; Pelizzi, C.; Picchioni, F.; Verdolino, V.; Goubitz, K.; Peschar, R.; Pelagatti, P. Eur. J. Inorg. Chem. 2008, 4462-4473.

(18) Dahlenburg, L.; Kuhnlein, C. J. Organomet. Chem. 2005, 690, 1-13.

(19) Madrigal, C. A.; Garcia-Fernandez, A.; Gimeno, J.; Lastra, E. J. Organomet. Chem. 2008, 693, 2535-2540.

(20) Braunstein, P.; Graiff, C.; Naud, F.; Pfaltz, A.; Tiripicchio, A. Inorg. Chem. 2000, 39, 44684475 . 
(21) Manoury, E.; Fossey, J.; Ait-Haddou, H.; Daran, J.; Balavoine, G. Organometallics 2000, 19, 3736-3739.

(22) Mourgues, S.; Serra, D.; Lamy, F.; Vincendeau, S.; Daran, J.; Manoury, E.; Gouygou, M. Eur. J. Inorg. Chem. 2003, 2820-2826.

(23) Lopez Cortes, J. G.; Ramon, O.; Vincendeau, S.; Serra, D.; Lamy, F.; Daran, J. C.; Manoury, E.; Gouygou, M. Eur. J. Inorg. Chem. 2006, 5148-5157.

(24) Routaboul, L.; Vincendeau, S.; Turrin, C. O.; Caminade, A. M.; Majoral, J. P.; Daran, J. C.; Manoury, E. J. Organomet. Chem. 2007, 692, 1064-1073.

(25) Le Roux, E.; Malacea, R.; Manoury, E.; Poli, R.; Gonsalvi, L.; Peruzzini, M. Adv. Synth. \& Catal. 2007, 349, 309-313.

(26) Labande, A.; Daran, J.-C.; Manoury, E.; Poli, R. Eur. J. Inorg. Chem. 2007, 1205-1209.

(27) Togni, A.; Bieler, N.; Burckhardt, U.; Kollner, C.; Pioda, G.; Schneider, R.; Schnyder, A. Pure Appl. Chem. 1999, 71, 1531-1537.

(28) Gómez Arrayás, R.; Adrio, J.; Carretero, J. C. Angew. Chem. , Int. Ed. Engl. 2006, 45, 76747715.

(29) Mateus, N.; Routaboul, L.; Daran, J. C.; Manoury, E. J. Organomet. Chem. 2006, 691, 22972310 .

(30) Routaboul, L.; Vincendeau, S.; Daran, J.-C.; Manoury, E. Tetrahedron: Asymmetry 2005, 16, 2685-2690.

(31) Audin, C.; Daran, J.-C.; Deydier, E.; Manoury, E.; Poli, R. C. R. Chim. 2010, 13, 890-899.

(32) Hounjel, L. J.; Bierenstiel, M.; Ferguson, M. J.; Mcdonald, R.; Cowie, M. Inorg. Chem. 2010, 49, 4288-4300.

(33) Carmona, D.; Lahoz, F. J.; Elipe, S.; Oro, L. A.; Lamata, M. P.; Viguri, F.; Sanchez, F.; Martinez, S.; Cativiela, C.; Lopez, M. P. Organometallics 2002, 21, 5100-5114.

(34) Carmona, D.; Medrano, R.; Dobrinovich, I. T.; Lahoz, F. J.; Ferrer, J.; Oro, L. A. J. Organomet. Chem. 2006, 691, 5560-5566.

(35) Kumar, P.; Yadav, M.; Singh, A. K.; Pandey, D. S. Eur. J. Inorg. Chem. 2010, 704-715.

(36) Altomare, A.; Burla, M.; Camalli, M.; Cascarano, G.; Giacovazzo, C.; Guagliardi, A.; Moliterni, A.; Polidori, G.; Spagna, R. J. Appl. Cryst. 1999, 32, 115-119.

(37) Sheldrick, G. M. Acta Cryst. A 2008, 64, 112-122.

(38) Spek, A. L. J. Appl. Cryst. 2003, 36, 7-13.

(39) Farrugia, L. J. J. Appl. Cryst. 1997, 30, 565.

(40) Frisch, M. J.; Trucks, G. W.; Schlegel, H. B.; Scuseria, G. E.; Robb, M. A.; Cheeseman, J. R.; Scalmani, G.; Barone, V.; Mennucci, B.; Petersson, G. A.; Nakatsuji, H.; Caricato, M.; Li, X.; Hratchian, H. P.; Izmaylov, A. F.; Bloino, J.; Zheng, G.; Sonnenberg, J. L.; Hada, M.; Ehara, M.; Toyota, K.; Fukuda, R.; Hasegawa, J.; Ishida, M.; Nakajima, T.; Honda, Y.; Kitao, O.; Nakai, H.; Vreven, T.; Montgomery, J., J. A.; Peralta, J. E.; Ogliaro, F.; Bearpark, M.; Heyd, J. J.; Brothers, E.; Kudin, K. N.; Staroverov, V. N.; Kobayashi, R.; Normand, J.; Raghavachari, K.; Rendell, A.; Burant, J. C.; Iyengar, S. S.; Tomasi, J.; Cossi, M.; Rega, N.; Millam, N. J.; Klene, M.; Knox, J. E.; Cross, J. B.; Bakken, V.; Adamo, C.; Jaramillo, J.; Gomperts, R.; Stratmann, R. E.; Yazyev, O.; Austin, A. J.; Cammi, R.; Pomelli, C.; Ochterski, J. W.; Martin, R. L.; Morokuma, K.; Zakrzewski, V. G.; Voth, G. A.; Salvador, P.; Dannenberg, J. J.; Dapprich, S.; Daniels, A. D.; Farkas, Ö.; Foresman, J. B.; Ortiz, J. V.; Cioslowski, J.; Fox, D. J. Gaussian 09, Revision A.01; Gaussian, Inc.: Wallingford CT, 2009.

(41) Hay, P. J.; Wadt, W. R. J. Chem. Phys. 1985, 82, 270-283.

(42) Hay, P. J.; Wadt, W. R. J. Chem. Phys. 1985, 82, 299-310.

(43) Ehlers, A. W.; Boehme, M.; Dapprich, S.; Gobbi, A.; Hoellwarth, A.; Jonas, V.; Koehler, K. F.; Stegmann, R.; Veldkamp, A.; Frenking, G. Chem. Phys. Lett. 1993, 208, 111-114.

(44) Marenich, A. V.; Cramer, C. J.; Truhlar, D. G. J. Phys. Chem. B 2009, 113, 6378-6396. 
